\title{
A Touristic Archaeological Study for a COLleCtion OF FUnERAL AND CHARITABLE ISLAMIC Establishments at BāB AL-NAȘR CEMETERY IN CAIRO
}

\author{
Hosam Hassan Abd el-Fadeel Hemeda \\ Faculty of TOURISM AND Hotels, Sadat City UNIVERSity, Egypt
}

\author{
Shaban Samir Abd- Elrazik Mohammed \\ FACULTY of TOURISM AND HOTELS, Minia UNIVERSity, Egypt
}

\begin{abstract}
This article aims to study five Funeral Islamic Mausoleums and one Charitable Islamic monument (Sabīl). These buildings date back to the $19^{\text {th }}$ and $20^{\text {th }}$ centuries at the cemetery of Bāb al-Nașr in Cairo published for the first time. These monuments are; the Courtyard of Muhammed Abu al-Ila, the Mausoleum of el-Sitt Amna, the Mausoleum of Hassan'Abbās, the Mausoleum of al-Mi'allim Muștafā Ibrāhìm alFahām, the Mausoleum of al-Hağ Ibrāhìm Hussiyn al-Zaiyāt and the Sabīl al-Hağ Ahmad Ahmmad al-Samāhī. The cemetery of Bāb al-Naṣr is considered one of the important Islamic Archaeological sites in Islamic Cairo that contains a lot of Archaeological Mausoleums. The article studies these six monuments through describing the architectural and decorative elements and calligraphic inscriptions on the facades of these monuments. The researcher could not describe these Monuments from inside because they are inhabited by people who are prevented any one from entering. The article recommends increasing the awareness to the significance of the monuments of Bāb al-Nașr cemetery and taking the necessary procedures for their registration upon the list of Islamic monuments, and ends with some suggested points of touristic development to the area of Bāb al-Nașr Cemetery.
\end{abstract}

Keywords: Bāb al-Nașr, Cemetery, Courtyard, Mausoleum, Sabīl, Touristic development. 


\section{INTRODUCTION}

\section{The Cemetery (ĞGBĀNT) OF BĀB AL-NAṢR}

Al-Maqrīzi ${ }^{-1}$ mentioned in his book al-Hitat when he was speaking about al-Husayniyah lane (Hārat al-Husayniyah ${ }^{2}$ ) that; "It was known by a group of purchased slaves ('Abīd al- Šrā') called al- Husayniyah.This lane is divided into two parts: the first lies outside Bāb al-Futū and its length is from outside Bāb al-Futūh to al-Handq. ${ }^{3}$ This part was occupied by the soldiers during the Fatimid Caliphs. The second part lies outside Bāb al-Nașr, and its length is from outside Bāb al-Nașr to alRaiydaniyya, ${ }^{4}$ and this part includes only Mușalla al- ${ }^{\prime} \bar{E}^{-}{ }^{5}$ during the Fatimid Caliphs, and from el-Mușalla to al-Raiydaniyya was free area without any building, and the the convoys of pilgrims came down in this

\footnotetext{
${ }^{1}$ Al-Maqrīzī, (Taqiy al-Dīn Aḥmad ibn 'Alī al-Maqrīz̄ì, d. 845/1442), (1998). alMawā'iz wa-l-i'tibār fī dikr al-Ȟițaț wa-l-ātāà, ed. Muḥammed Zinhum, Madiḥa Elšrqawī, (Maktabat Madbūlī, vol.2), 411, 412.
}

${ }^{2}$ Haarat al-Husayniyah: This lane is one of Fatimid Cairo lanes. It was said this lane was known with this name according to a group of purchased slaves ('Abīd al- Šrā'), while the historian Ayman Fauad el-Sayyid says, this lane was attributed to the commander al- Hussiyn ibn Ğawhar. It was occupied at the first by a group of purchased slaves ('Abīd al- Šrā'), and after that it was occupied by a group of Armenians in the sixth Century of Hegra during the reign of al-Sultān al-Malik al-Kāmal al-Ayubī. The present site of this lane as the historian Muhammed Ramzi mentioned is the great lane that located towards Bāb al-Futūh. It is today mediated from south to north with alHusayniyah street,and al-Baiyumī street from Bāb al-Futūh to the square of al-Amīr Fārūk. For More, See:

Ibn Tağrī Bardī (Ğamāl al-Dīn Abī al-Mahāsin Yūsif, d. 874/1470), (1963). al-Nuğūm al-Zāhirah fi Milūk Miṣr wa- al-qāhira,,ed. Muḥammed Ramzī, (Nushah Mușawarah min Dār al-Kutub al-Mașriyya, al-M' ūssa al-Mașriyya li- al-Ta' līf wa al-Našr,Cairo, vol.4), 45; Ibn 'Abd-el-Zāhir (Muhiyī al-Dīn Abu al-Faụl 'Abdallah ibn 'Abd-el-Zāhir al-Maṣrī, d. 692/1293), (1996). al-Rawḍa al-Bahiyya al-Zāhira fi Huițaț al-Mu'ziyya al-qāhira, ed. A.F. Sayyid, (Maktabat al-Dār al- 'Arabiyya lilkitāb, Cairo),122.

${ }^{3}$ Al-Handq: It was a village outside Bāb al-Nașr. It was known at the first with Miniyyat al- 'Asbug. When the commander Ğawahr al- Șiqilī established Cairo, the Moroccans ordered to dig a trench intended to fight al-Qarāmitah behind this trench and then became a beautiful garden later during the rule of the Fatimid Caliphs. al-Maqrīzī, al-Hुițaț, vol.2, 684.

${ }^{4}$ Al-Raiydaniyya : It is located outside Bāb al-Nașr, and it was a garden for one of the servants of the Fatimid Caliph al- 'Azīz bi-Illah who known as Raiyydān al- Șiqillī. al-Maqrīzī, al-Hुițaț, vol.2, 690.

${ }^{5}$ Muṣalla al- Eīd: This Mușalla was built by the great leader Ğawahr al- Șiqilī for al'Eīd prayer in (358A.H.). It is located outside Bāb al-Nașr and it was repaired by the Fatimid Caliph al-'Azīz bi-Illah. For More, See:

al-Maqrīzī, al-Hुițaț, vol.2, 257-265. 
free area. After the year of (450 A.H./1058 A.D.), Amīr al-Ğuiyūš Badr alĞamāli ${ }^{6}$ established a great cemetery including his tomb and the tomb of his son al-Afdal ibn Amīr al-Ğuiyūš ${ }^{7}$ to the north western side of Muṣalla al- 'Eīd outside the gate of Bāb al-Nașr"' So, the Cemetery of Bāb al-Nașr lies to the north of the Fatimid Cairo, and it was built after the year of (450 A.H./1058 A.D.), when Amīr al-Ǧuiyūš Badr al-Ǧamālī established a great cemetery including his tomb and the tomb of his son al-Afdal ibn Amīr al-Ğuiyūš to the north western side of Mușalla al- 'Eīd outside the gate of Bāb al-Nașr.

The Cemetery of Bāb al-Nașr is considered one of the most visited shrines, and there was no cemetery in the desert like that as it included the tombs of 'Ulamā' (Muslim scholars), Awliya' (guardians), jurists of Islam and historians. The people established in this cemetery many tombs, Zāwiyā and mosques. But most of these buildings were vanished and the cemetery went to wrack and ruin. ${ }^{8}$

Nağim al-Dīn Street is considered the main street of this cemetery. Formerly, it was called "al-Maqāber Street as mentioned

\footnotetext{
${ }^{6}$ Badr al-Ğamālī: He was Abū '1-Nağm Badr ibn 'Abdallah al-Ğamālī al-Mustanșirī al- Armin̄ī, better known as Badr al-Ğamālī . He was a vizier of the Caliph al-Mustanșir. He has many titles such as; Amīr al-Ğuiyūšs, al-Sayad al-'Ağal and al-Wazīr al- Amīr, Sayf al-' Islām and Nāṣr al-Imām. He was an Armenian Mamluk born nearly in (407-1016 A.H.), and died in (486-1095 A.D.). For More, See, Al-Maqrīzī (Taqiy al-Dīn Aḥmad ibn 'Alī al-Maqrīzī, d. 845/1442), (2001). 'It āz al- Ḥunfā fi 'Ahbār al-' A'imah al- Fāṭimiyīn al-Hुulfā, ed. Muḥammed 'Abdelqadir Aḥmad Rị̣a, (Dār al-Kutub al-'Ilmiyya, Beirut, vol.1), 147; Ibn Tag̉rī Bardī, al-Nuğūm al-Zāhirah, vol.5, 138.

${ }^{7}$ al-Afdal ibn Amīr al-Ǧuiyūš: He is Abu al-Qāsm Šāhinšhāh al-Malik al-Afụal ibn Amīr al- Guuiyūš Badr al-Ğamālī. He took over the ministry in (487-515A.H. / 10941121A.D.) for twenty-eight-year. He was killed in (515 AH / 1121 AD) in a conspiracy orchestrated by the Caliph al- 'Āmir bi Aḥkām Illah with his minister, son of alM'aamūn al-Bațāihī. For More,See:

Ibn Hुilkān (Abu al-'Abbās Aḥmad ibn Muḥammed al-Šāfi '̄ị, d 681/1275), (1987). Wafiyāt al-'Aiyān wa 'Anba' 'Abnā' al-Zamān, ed. 'Iḥsān 'Abbās, (Dār Șādir, Beirut, vol.3), 235; Muḥammed Ḥamdī al-Manāwī, al-Wizārah wa-al-Wuzāra' fi al-'Așr alFāṭimī,( Dār al-Mā' rif bi Miṣr, Cairo), 313.

${ }^{8}$ For more about the Cemetery of Bāb al-Nașr, See: Fatḥ̄ al- 'Azhrī, Tarwat, (2016). "Ğabānt Bāb al-Naṣr in Cairo wa R'uiyya šāmilah li Waḍ ihā 'Alā Harițat al-Siyyaḥah al-Dīniyyah wa al-'Iršād al-Siyyāḥī", (Ph.D. thesis, Faculty of Tourism and Hotels, Minia University).
} 


\section{The Courtyard (Ḥūš) of Mụ̣ammed Abu el-'Ila}

This courtyard $\left(\mathrm{H}_{\bar{u}} \overline{\mathrm{s}}^{9}\right)$ is located at the street of Nağim al-Dīn at Bāb alNașr Cemetery (Fig. 1) in the eastern side of the tomb of Swiss traveller Johann Ludwig Burckhardt ${ }^{10}$ (Saydī Ibrāhīm al-Mahdī al- Enğlīzī as alĞabrtī mentioned $\left.{ }^{11}\right)$. It was erected by Muhammed Afndī Abu el- 'Ila alQammāš in (1221 A.H. / 1806 A.D.).

\section{THE DESCRIPTION}

This courtyard has only one facade, the eastern facade is the main one (Fig.6, pl.1). It directly overlooks al-Maqāber Street previously. It is considered the main façade of the courtyard because it includes the main entrance $\left(\mathrm{Madhl}^{12}\right)$, which is a rectangular entrance door that is closed by

\footnotetext{
${ }^{9}$ Huuš: This word means in the archeological term as a courtyard or the covering court which it was located behind the grave of Sultan on the Amīr and it was contain a number of tombs, and it was mentioned in the Mukluk's documents by different words such as a smallest courtyard or sky courtyard and a largest courtyard, For More, See: Muhammed Rizq, 'Asām, (2000). Mu 'găam Mușțaalhāt al-'Imārah wa- al Funūn al-Islāmiyya, (Maktabat Madbūlī, Cairo, 2000), 87, 88.
}

${ }^{10}$ Johann Ludwig Burckhardt: He was a Swiss traveller born in Switzerland in (1199 A.H /1784 A.D.). He is best known for his rediscovering the ruins of the ancient city of Petra in Jordan. He came to Cairo in (1227 A.H. /1812 A.D.). After spending four months in Cairo, he decided to journey up the Nile River to Upper Egypt and Nubia. He managed to excavate the temple of Abu Simbel by the aid of his friend Giovanni Belzoni in (1232 A.H. 1817A.D.). After that, He journeyed to the Red Sea and resolved to make the pilgrimage to Mecca as this would enhance his credentials as a Muslim. He was died with dysentery in Cairo on (1232 A.H. 1817A.D.). He was buried as a Muslim in his tomb at Bāb al-Nașr Cemetery, and the tombstone over his grave bears the name of alŠayh Ibrāhīm al-Mahdī. On this tombstone wrote in Arabic" The Swiss traveller al-Šayh Ibrāhīm al-Mahdī sleeps here, he was born in (1199 A.H.) and died in (1232 A.H.)". All these information are available online at https://ar.wikipedia.org.

${ }^{12}$ Al- Ğabrty ('Abdalraḥmān ibn Ḥassan d.1249/1825), (1998). 'Agā'b al-Atâ̄r fi elTrāğm wa-l- Ahbār, ed. 'Abdelrḥīm 'Abdelrḥman 'Abdelrḥīm, (Dār al-Kutub alMișriyya, Cairo, vol.2), 409.

12 The Main entrance (Madhl): The first clear entrance in religious architecture in Egypt, is the western entrance of al- Hakim mosque (380- 403 A.H/ 990- 1013 A.D), which is similar to the entrance of al- Mahdiyya mosque in Tunis (308 A.H./ 921 A.D.).The Architect in the $19^{\text {th }}$ century is concerned with the shape and formation of the entrances of Islamic buildings. The entrances of the Islamic establishments have many shapes and formation such as: the entrances crowned with trefoil arches, the entrances topped with hood that decorated with tiers of stalactites, and the entrances with different types of arches, like semi-circular, pointed arch, straight arch, and horse- shoe arch. The location of the entrance is varies from building to other. Some entrances are located in the middle of the façade, while other entrances are located to the left or right corner of the façade. Generally, the Islamic architect gave much care to the entrances of the Islamic building, 
two-leaf wooden door that has no decoration (pl.2). To the left, the architect executed a rectangular wooden two-leaf window on two levels that is encircled from outside by a screen of metal castings with geometric and floral motifs depicting nature. The façade is decorated from outside with shell-shaped pivotal floral decorations and radial geometric decorations. The upper part of façade is decorated with the same floral and geometric patterns, circular shapes with three bands or lines pending down from them. In addition, there is a stone panel containing the foundation text (pl.3) of the courtyard. It consists of two lines inscribed in Riq'a script ${ }^{13}$ says that:

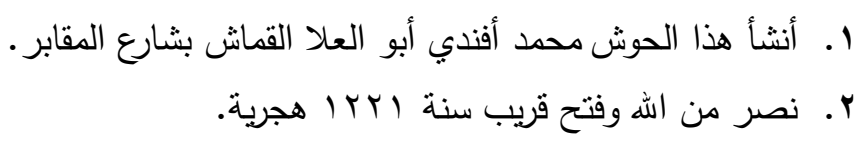

\section{The Transliteration}

1. 'Anša' Haḍā al-Ḥ̂ūš Muḥammed Afndī Abu el- 'Ila al-Qammāšs biŠāri' al-Maqāber.

2. "Nașrun Mina Allāhi Wa Fatḥun Qarīb", Sanat 1221 Hiğriyya.

\section{The Translation}

1. This courtyard was erected by Muhammed Afnd ${ }^{14}$ Abu el- 'Ila alQammāš at al-Maqāber Street.

since the begging of Islamic era in Egypt. For More about the entrances in the $19^{\text {th }}$ century. In this study, there are some types of entrances such as the semi-circular arched entrance (pl. 8) and trefoil arched enrrance (pl. 10), See: 'Abdelfatāh 'Abdelwahāb, 'Abdelwahāb, (2006). "al-Ṭirāz al-Fan̄̄ wa- al-Mi'mārī li Masāğid al-Qğhirah fi al-Qarn al-țālit 'Ašr al-Hiğrī (1215-1318 A.H.) al-Tāsi' 'Ašr al-Milādī (1800-1899 A.D.)", (Master. Thesis, Faculty of Archaeology, Cairo University),346-353.

${ }^{13}$ Riq a Script: The Opinions differed about the origin of the Riq'a Script, and agreed that it is one of the types of calligraphic script of the Turkish school, has been used by the Ottomans in their official establishments for easier writing more than the Nashi inscription and has spread in most countries of the Ottoman Empire. The Riq'a Script is distinguished with its short letters. The Riq'a Script is one of the easiest types of Arabic scripts in terms of writing and is characterized by clarity and integrity of the letters, and is also a line that does not tolerate the composition or composition in the formulation of a sentence, so it has been less used in the areas of decorative and artistic in general and architecture in particular. For More, See: Ğum'a, Ibrāhīm, (1979) Qișat al-Kitāba al'Arbiyya, (Dār al-Ma'ārif, Cairo), 109; 'Alī Nașra,Muḥammed, (2001). "Ğamāliyyat alKitbāt al-'Arbiyya fi al- 'Imārah al-Islāmiyya Kamadhal li-Tağmīl Wağhāt al-Mabānī", (Ph.d. thesis, Faculty of Art Education, Hilwān University), 14.

${ }^{14}$ Afndī :This title is one of the honorable titles. It was said in its origin that it is derived from the Greek colloquial word (Effendis), which is taken from the ancient word (Aventuns), which was introduced into the Turkish language and was used by the Turk 
2. "Victory from Allah and an imminent conquest ${ }^{15}$ ", in 1221 A.H.

3. This courtyard has a dome (Qubba ${ }^{16}$ ) take the shape conical helmet on an octagonal drum ending with a bulging pillar. It is in a poor condition of preservation. As for the dome, it takes the form of the tower that spread in the civil buildings. (pl.4).

\section{The Mausoleum of El-SitT Amna}

This Mausoleum is located at Bāb al-Nașr cemetery (Fig.1). The original founder of this courtyard is unknown, but there is a renewal foundation text panel in the name of el-Sitt Amna dated to (1239 A.H. / 1823 A.D.).

\section{THE DESCRIPTION}

This Mausoleum has one facade, (the eastern façade). It is considered the main façade as it includes the main entrance block which is rectangular with a wooden door that is depriving of decoration (pl. 5). On the top of the entrance, there is a square panel containing an inscription of seventh poetic lines in Tulut script ${ }^{17}$ says as following (Fig.2, pl. 6):

in the thirteenth century A.D. It refers to the owner, the lord and the master. This title was used for religious and civil functions, jurists and scholars.

Al-Sa '̄id Suliymān, Aḥmad, (1979). Ta'ṣ̄il ma Warad fi Tarīḥ al- Ğabrty min a-Dah̄il, (Dār al-Ma rif, Cairo,197920; Taiymūr, Aḥmad, (1950). al-Rutab wa- al-'Alqāb alMișriyya, (Dār al-Kitāb al-'Arabī, Cairo,1950,66; Barakāt, Mușțafa, (2000). al-'Alqāb wa- al-Waẓā' if al- 'Uțmāniyya,Dirāsa fi Tațwur al-' Alqāb wa- al-Waẓā' if mund al-Fath al- 'Uțmānī li Miṣr ḥatā 'Iilg̀ā' al- Ḩilāfa al- 'Uțmāniyya, (Dār Ġarīb li al- Ṭibā' ah wa -al -Nšar wa al-tawzī' , Cairo), 150-153.

${ }^{15}$ Holy Quran, Surat a- Șaf, verse (13).

${ }^{16}$ The Dome (Qubba): is one of the most important architectural elements that used in the Islamic architecture. It was used as a type of decoration for covering the buildings. It also used to be apart for lighting and ventilation inside the Mosque or Madrasa or the Mausoleum. There are many different styles for the dome such as; conical dome, circular dome, the dome in the shape of the onion and the ribbed dome. It is also used to mean a mausoleum. In this study appeared the shape of conical dome (pl. 4) in the Courtyard of Muhammed Abu el-'Ila (1221 A.H. / 1806 A.D.). For More, See:

Center for Planning and Architectural Studies, Center for Revival of Islamic Architectural Heritage, Principals of Architectural Design and Urban Planning During the Different Islamic Ears, (Organization of the Islamic Capitals and Cities,Jedda, Saudi Arabia, 1992), 484; Șālah Lam 'aī Muștafa, (1977). A- Turāt al-Mi mārī al-Islāmī fi Miṣr, (Dār a-Nahụah al-' Arabiyya, Beirut), 25-27.

${ }^{17}$ Tulut Script: It is considered the third script of Arabic calligraphy after Kufic and Nashī scripts. The Tulut script is also characterized by the complication of the configuration of its letters and the interlacing of words into one another expressing the cleverness of the Arabic calligrapher. It is widely appeared in the Ottoman era, and reached to the zenith of aesthetics in terms of the proportions of letters and the 


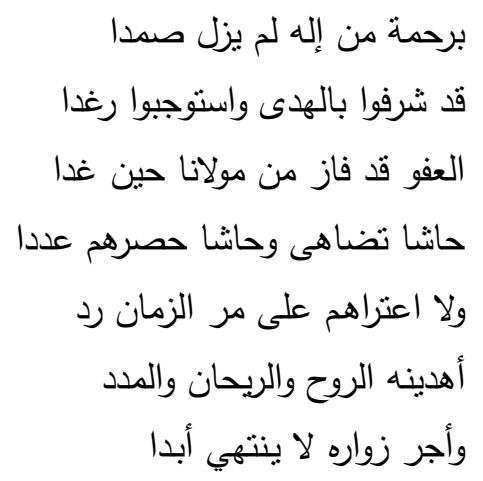

برحمة من إله لم يزل صمدا

قد شرفوا بالهدى واستوجبوا رغدا

العفو قد فاز من مولانا حين غدا

ولا اعتراهم على مر الزمان رد وهائه

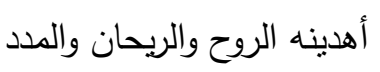

وأجر زواره لا ينتهي أبدا

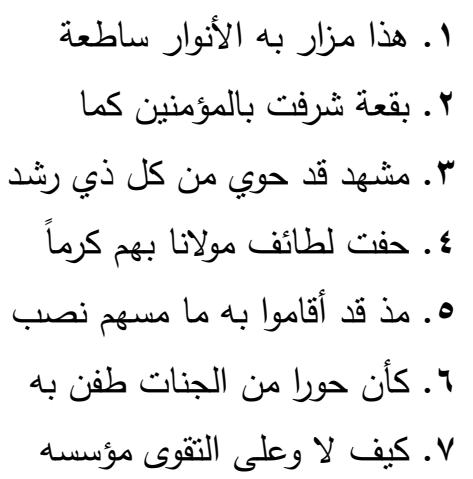

\section{The Transliteration}

1. Haḍā Mazārun Bihi-al-Anwāraw Bi-raḥmatin min Ilahin lam yazal Sāṭi atun Șamadan

2. Buq'atun Šarufat bi- el- qad Šurrrifū Bi-l- Huda waMu'minīna kamā Stawgabu Ragada

3. Mašhadun qad hawā min kull al-'Afwa qad fāza min mawlāna zi-rašadin hīna gada

4. Ḥaffat lata'ifu mawlāna bihim Ḥāša tuḍāhī wa- hạaša hașarahum karaman

\section{'Adada}

5. Mud qad aqāmū bihi ma- Wa-la I'tarāhum 'ala marr ezmassahum nasabun zamāni radd

6. Ka'ana Hūran min al-ğannati tufna bihi

Ahdaynahu ar-rawḥa war-raiyḥ̄na wa al-madada

7. Kayfa la wa-'alat-taqwa Wa-ağri zuwwārihi la yantahi abada mū'assesihi

\section{The Translation}

1. This is a shrine shining with the lights of the mercy of God, the Everlasting.

magnificence of its calligraphic forms created by the Turkish calligraphers. These forms included varieties of paintings, artifacts, ornamentations and other masterpieces of the Turkish school of calligraphy. In addition, their achievements can be seen in the inscriptions of the Ottoman architecture that included gorgeous creations of the Tulut script by Turkish calligraphers. For More, See:

Yassin Hamad Safady: Islamic Calligraphy, (Thames and Hudson, London, 1987), 22;

Center for Planning and Architectural Studies, Principals of Architectural Design, 429. 
2. A spot honored by the believers who were honored with guidance and deserved his blessings.

3. A cemetery of every guided who deserved His mercy and would enjoy more in the afterlife.

4. Our Lord's kindness surrounded them. No matter what they do, they are limited to a number.

5. Since their death, they rested in eternal peace. And they do not recognize them over time.

6. As if Virgins of Paradise were wandering the place with rest and bounty and a garden of pleasure.

7. Why not and they were pious and visited by innumerable visitors whose charities for the dead never ends.

To the right of the entrance door, there is a renewal panel containing the renewal text on the upper part. It has three lines of inscription in Tulut script that says (Fig.3, pl.7).

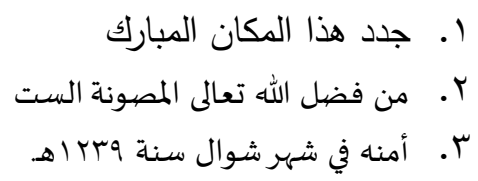

\section{The Transliteration}

1. Ğadada Haḍā al- Makān al-Mubārak. ${ }^{18}$

2. Min Fadl el-Ilah T'āla al-Mașūna ${ }^{19}$ al-Sitt. $^{20}$

${ }^{18}$ Al-Mubārak (the Blessed): One of the titles of honor in the Mamluks' era. It described some buildings as "Manzil Mubārak / a blessed house". This title is appeared in the foundation text of some Mamluk establishments like the Hān of al- Amīr Qūsūn in al- Ğamāliyya as the text says ('Anša' Haḍā al- Hāan al-Mubārak). It was used also to describe the correspondence as it was said (Wardat al-Mukātaba al-Mubāraka), See: AlQalqašandī (Abu al- 'Abbās Aḥmad ibn 'Alī, d. 821/1418), (1914). Șubḥ al-a 'šā fī șinā' at al-inšā, Dār al-Kutub al-Mișriyya, Cairo,1914, vol.6, p.188; Al-Bāša, Hassan, (1978). al'Alqāb al-'Islāmiyya fi al- Tārīh wa -al-Watāà'q wa-al-' Ațār, (Dār al-Nahụa al- 'Arabiyya, Cairo), 447; Hassan Hemeda, Hosam, (2007). "Islamic Archaeological Sites in alĞamāliyya street in Cairo and their Tourist Development", (Ph.d. thesis, Faculty of Tourism and Hotels, Minia University,2007), 150.

${ }^{19}$ Al-Mașūna: It means "Protected" .It is a title of women. This title was mentioned in many foundation texts dated back to the Mamluk era. It was appeared in foundation text of the Madrsa of Tatar Hुātūn al- Ḥiğāziayah al- Ğamāliyya Street as it was said (al-' Adr al-Mașūna). It was re-used in the inscriptions of the $19^{\text {th }}$ century in some buildings as we see in the foundation text of the Courtyard of el-Sitt Amna in this study. This title is used in $19^{\text {th }}$ century as a title of honor and to refer the Social position.

al-Qalqašandī, Șubh al-a šāā, vol.6, 78; Al-Bāša, Hassan, al-'Alqāb al-'Islāmiyya, 472; Hassan Hemeda, Hosam, (2007). Islamic Archaeological Sites in al- Ğamāliyya, 83. 
3. Amna Fi Šahr Šawwāl Sanat 1239 A.H.

\section{The Translation}

1. This blessed place was restored.

2. From the blessing of the God al-Mașuna al-Sitt.

3. Amna in the month of Šawwāl in the year of 1239 A.H.

This courtyard is very simple and in a poor condition of reservation. It has no decorative inscriptions except for the previous one. The last line of the inscription is obliterated due to faulty and non-specialized restoration process. The researcher could not describe the Courtyard from inside because it is inhabited by people who are prevented any one from entering to the Courtyard.

\section{The Mausoleum of Ḥassan'A AbBās}

This mausoleum is located at Nağim al-Dīn Street in Bāb al-Nașr Cemetery (Fig.1), in the western side of the mausoleum of Yūnis al-S' adī ${ }^{21}$. It was built by Hassan 'Abbās, and his brother Muhammed Bassyūn̄̄ in (1302 A.H. / 1884 AD).

\section{THE DESCRIPTION}

The main façade of this mausoleum has the main entrance. It is made of stone in the form of an opening with a two-leaf Iron door (Fig.7, pl.8). It is decorated with floral ornaments. It is topped by a foundation text that contains the renovation text of this mausoleum. It is a square panel of marble with three lines written in Tulut inscription says that (Fig.4, pl.9):

\footnotetext{
${ }^{20}$ Al-Sitt "Lady": A general title of women. It was often used before names. It was used in archaeological inscriptions and was mentioned in a funeral inscription dated back to Saffar (611 A.H.) in al-M'ala Cemetery in Mecca. It was mentioned also in the marble cenotaph in the mausoleum of the Madrsa of Um al-Sultān Š 'bān as a composite title (Sitt al-Sittat) in (117 A.H.).

Ḥassan al-Bāša, al-' Alqāb al-'Islāmiyya, 317; Muṣṭafa Barakāt, al-'Alqāb wa- al-Wazāà if al-'Utmāniyya, 262.

${ }^{21}$ Qubbat (Mausoleum) Yūnis al-S ' adī: It was firstly the tomb of Badr al-Ğamālī, the first tomb in the cemetery of Bāb al-Nașr. He is Yūnis ibn Yūnis ibn Mas id al-Quraši al- Šibānī. His origin is ttributed to Šaiybah ibn Oțmān ibn Țalhạa and his seventh grandfather is Qusay the grandfather of Prophet Peace is upon him. This dome was previously known as the dome of Qurqumāš , but is known now as the tomb of Šaiyh Yūnis al-S 'adī al- Šibānī the grandson of Šaiyh Sa'd al-Dīn al- Ğibbāwī. al- Šaiyh Yūnis was buried in this dome in (919 A.H.); Al- Sahawī (al-Hāfiz Šams al-Dīn Muhammed Abu al- H̄īr Muḥammed ibn 'Abdalrman, d. 902/1446), (1968). Tuhfat al'Ḥbāb wa Buggiyat a-Ṭulāb fi al- Hiițạ wa al-Mazārāt wa al-Biqā' al-Mubārakāt, (Maktabat al-Kuliyāt al-Azhariyya, Cairo, 1968), 37.
} 


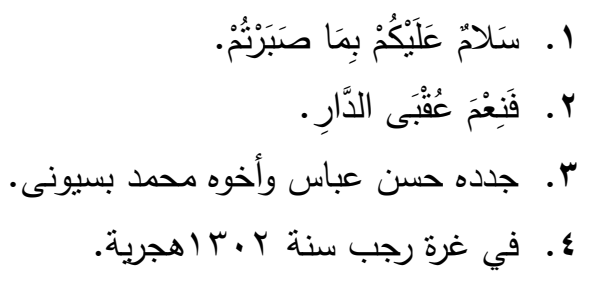

\section{The Transliteration}

1. Salāmun 'Alaykum Bimā Șabartum.

2. Fani 'ma 'Uqbā Ad-Dār.

3. Ğaddadahu Ḥassan 'Abbās wa Ahūh Muḥammed Bassyūn̄̄.

4. Fi Gurrat Rağab Sanat 1302 Hiğriya.

\section{The Translation}

1."Peace be upon you for what you patiently endured".

2."And excellent is the final home ${ }^{22 "}$.

3. It is renewed by Hassan 'Abbās and his brother Muhammed Bassyūnī.

4.In the beginning of Rağab (1302 A.H.).

The architect implemented two windows on this façade, one to the right side and the other on the left. As for the former, it is a rectangular entrance with an outer screen of metal castings, while the other window is relatively larger and consists of two levels. The facade is very plain and devoid of any decorations. It is in a very poor condition of preservation.

\section{The of Mausoleum AL-Mi allim MușṬAfā IbrāHĪM AL-Fạ̣ĀM}

This mausoleum is located at Nağim al-Dīn Street in Bāb al-Nașr Cemetery (Fig.1), in the eastern side of the mausoleum of Yūnis al-S adī. It was established by al-Mi 'allim ${ }^{23}$ Muṣtafā Ibrāhīm al-Faḥām in (1335 A.H. / 1916 A.D.).

\footnotetext{
${ }^{22}$ Holy Quran, Surat a- Ra'd,verse (24).

${ }^{23}$ al-Mi allim: This word is appeared on many Islamic monuments as a title or as a function. It was used as a title of the skilled craftsman who oversees other manufacturers or who had the grace of teaching other manufacturers of his craft. It appeared on many of the Islamic artifacts attached to the names of the builders, carpenters and metal makers. It appeared as a title for bronze Candlestick Maker in (730 A.H.). This Candlestick is exhibited now in Museum of Islamic Art. Hassan al-Bāša, al-' Alqāb al-'Islāmiyya, 478; Al-Bāša, Hassan, (1965). al-Funūn al'Islāmiyya wa al-Waẓ à'f 'alā al-'Atāar al- 'Arbiyya,( Dār al-Nahụa al- 'Arabiyya, Cairo, vol.3), 1110.
} 


\section{THE DESCRIPTION}

This mausoleum has only one facade (the northern façade), which overlooks directly Nağim al-Dīn Street. It is divided into three parts: the right, the middle and the left (Fig.8, pl.10).

ThE RIGHT PART: The upper part of the façade is decorated with a row of Crenellations (Šurāfāt) ${ }^{24}$ in trefoil-shaped plant leaf. It has a rectangular window opening that is closed from outside by square-shaped wooden castings. In addition, it is closed from inside by two wooden leaves that are devoid from decorations. On each side of the window, there is an engaged column with a circular shaft and Ionic-shaped base and capital. The window is topped by a stone rectangular panel of inscriptions that includes a Qur'anic verse in high-relief Tulut script. It consists of one line that is inscribed in black and reads: "إنَّا فَنَحْنَا لَكَكَ فَتْحَاً" مُبِيناً

The TransLiteration: "Innā Fataḥnā Laka Fatḥāan Mubīnā"

The Translation: "Indeed, We have given you, [O Muḥammad], a clear conquest". ${ }^{25}$

${ }^{24}$ Crenellations (Cresting), (ک̌urāfāt): The Crenellations were used in crowning the facades before Islam in Assyrian and Iranian buildings. The earliest example of this Architectural element appeared in the mosque of Ibn Tulūn on the the shape of dolls. In the Fatimid period, Stepped Crenellations (al- Šurāfăt al-Musananah) were used in al Azhar mosque (369- 361 A. H. /970-972A.D.). In the Ayyubid and Mamluk periods, the Stepped Cresting were appeared in a lot of Islamic establishments, like the mausoleum of al- Șālih Nağim al- Dīn Ayyūb (647- 648 A.H /1249- 1250 A.D.), and the mosque of al- Zahir Baybars Mosque (667. A.H. / 1269 A.D). The earliest example of leaf- shaped cresting in Egypt is founded at Sanğar al- Ğāwilī mosque (703 A. H/1303- 1304 A .D.). After that, different types of crenellations developed, such as the trefoil shapes and the stepped crenellations. In this study the trefoil plant leaf- shaped type of crenellations is crowned the facade of the mausoleum of al-Mi'allim Muștafā Ibrāhīm al-Fahām (pl.10,12,14). This type of crenellations is existed in many Islamic building especially the Funeral and religious buildings date back to the $19^{\text {th }}$ and the beginning of the $20^{\text {th }}$ centuries like the mosque of al- Imām al-Šafa 1 (1303-1309A.H./1885-1891A.D.), the mosque of al- 'Ašmāwī (1267A.H/1850 A.D.), the mosque of Sālih Abu Hadīd(1280-1284 A.H. /1863 -1867A.D.), the mosque of Qūsūn(1299-1311A.H./1873-1893A.D.) and the mosque of al- Sayyidah Nafĩsah(1314-1316A.H./1893-1895 A.D.). For More about the development of the Crenellations, See, Creswell (K.A.C): (1940). Early Muslim Architecture,(Oxford, London, II214; Muḥammed Rizq, 'Asām, (2000). Mu'ğam Mușțaalhāt al-'Imārah, 161-163; Nazīf, 'Abdelsalām, (1989). Dirasāt fi al-'Imārah al'Islāmiyya, (al-Hay' a al-Mișriyya al- 'Āmma li-l-Kitāb, Cairo), 74-76.

${ }^{25}$ Holy Quran, Surat al-Fath, verse (1). 
It is encircled with a decorative cartouche topped by a plain tympanum. The whole cartouche is flanked by frets with looped moldings. These are topped by a stalactite consisting of three stalactites in two levels. It ends from the upper part with a row of trifoiled crenellation in the plant shape.

The LefT PART: It is almost similar to the right side in terms of the architectural and decorative description, except for the inscription that reads: "اذخخُؤهَا بِنَلامٍ آمِنِينَ"

The Transliteration: "Adhulūhā Bisalāmin 'Āminīn"26

The Translation: "Enter it in peace, safe [and secure]".

The Middle ParT: This part is higher one meter than the rest of the façade. It was built as such to be distinguished as a main entrance to the mausoleum. It is topped by a row of trefoil crenellation in the plant shape. There are two stone steps leading to the entrance block that has the entry door. It is rectangular and enclosed by a newly manufactured Iron door topped by a lintel including the foundation text of the mausoleum. The lintel is a stone rectangular panel carved with a high-relief (Naḥt Bāriz) ${ }^{27}$ Tulut inscription in white says that (pl. 11):

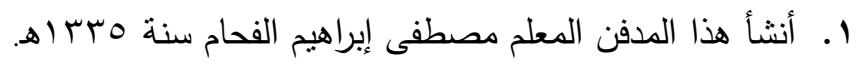

The Transliteration: "'Anša' Haḍā al-Madfan al-Mi' allim Muṣtafa Ibrāhim al- Fahāām Sanat 1335 A.H.".

The Translation: "This Mausoleum was established by al-Mi'allim Muṣtafa Ibrāhīm al- Faḥām Sanat 1335 A.H.".

This panel is followed by a plain tympanum (Nafis) ${ }^{28}$ then a reliving arch ('Aqd 'Atāq). ${ }^{29}$ The entrance is crowned with a trefoil arch ('Aqd

\footnotetext{
${ }^{26}$ Holy Quran, Surat al- Hiǧr, verse (46).

${ }^{27}$ High-Relief (al-Naḥt Bāriz): It is an artistic form in which the outer shape of the element is determined before the artist engraves the background around it So that, the element itself is higher than the level of the background itself. When this style of highrelief is easier than the bas-relief, it became preferred for implementing of inscriptions on solid materials like marble and this is why such engraving is performed very slowly and carefully. The foundation text of al-Mi'allim Mușțafā Ibrāhīm al-Fahām was implemented with this method (pl.11). For More about the method of High-Relief (alNaḥt Bāriz), See:

Howary et Rached, Steles Funeraires, (Le Caire, tome I, 1932), 7; Muḥammed Ibrāhīm, Wafā', (2003). "al-Ruh ām fi al- 'Așr al-Mamlukī al- Ğarkasī bimadīnat al-Qāhira, Dirāsa 'Atiriyya Faniyya", (Master Thesis, Faculty of Arts, Tanta University, 2003), 7678.

${ }^{28}$ The Tympanum (Nafīs): Tympanum is the semi-circular or triangular decorative wall surface upon the entrance, bounded by a lintel and reliving arch. Most Islamic buildings have this element. Tympanum appeared for the first time in Islamic architecture in Egypt
} 


\section{Madān'ì). ${ }^{30}$ The hood of the arch is decorated with stalactites (Muqrnșāat), ${ }^{31}$ flanked by continuous molding (al- Ğift al-Lā' b) ${ }^{32}$ with}

free of decoration like the Tympanum in this study. At the end of the Fatimid period the tympanum was developed and decorated like the tympanum in the entrance of al- Șālih Țalāi mosque (555 A.H. / 1160 A.D). The tympanum was developed in the Ayyubid, Mamluk, and Ottoman Islamic architecture. In the $19^{\text {th }}$ and the beginning of the $20^{\text {th }}$ centuries the time of this study, the tympanum was used upon several entrances and windows of Funeral, religious and civil buildings like the Mausoleum al-Mi'allim Muștafă Ibrāhīm al-Faḥām in this article (pl.10,11). . For More, See:

Fahmī Karīm, Šāhinda, (1987) "Ğawāma' Wa-Masğid 'Umarā' al- Nāṣir Muhammed ibn Qalāwūn",( Ph.d. Thesis,Faculty of Archaeology, Cairo University), 388-390.

${ }^{29}$ The Reliving Arch ('Aqd 'Atāq): This arch is a segmental one which is used to relieve arches from the vertical forces, and was found in the Hawrans foundations in Damascus in the first century. In Islamic architecture, the earliest example of the Relieving arch was found in Qașr al- Hayr al-Šarqī (110 A. H., 728-729 A.D.). The tympanum was developed in the Ayyubid, Mamluk, and Ottoman Islamic architecture. In the $19^{\text {th }}$ and the beginning of the $20^{\text {th }}$ centuries the time of this study, the Reliving Arch was used over several entrances of Funeral and religious buildings like the Mausoleum al-Mi 'allim Muștafā Ibrāhīm al-Faḥām (pl.10,11). in our study.

Center for Planning and Architectural Studies, Principals of Architectural Design, 453.

${ }^{30}$ The Trefoil Arch ( 'Aqd Madān'ì ): It was one of the types of arches. It was used widely in the main entrances of Islamic buildings in different periods in Egypt especially in Mamluk and Ottoman periods. The earliest example of trefoil arch was found in the portal of al- Bunduqdariyya Madrasa (660 A.H./ 1262-1263 A.D.). The portal arch of Zin al- Dīn Madrasa (697 A.H, 1298 A.D.) is the earliest still existing example. In the $19^{\text {th }}$ and the beginning of the $20^{\text {th }}$ centuries the time of this study, the Trefoil Arch was used to crown several entrances Islamic buildings like the Mausoleum al-Mi'allim Muștafā Ibrāhīm al-Fahāām (pl.10). in our study.

Center for Planning and Architectural Studies, Principals of Architectural Design, 452.

${ }^{31}$ Stalactites (Muqrnșāt): Stalactite is one of the most characteristic features of Islamic architecture and is used throughout most of the Muslim world. Muqarnas is usually associated with domes, doors and niches-although it is often applied to other architectural features and is sometimes used as an ornamental band on a flat surface. The earliest example of stalactites was found at Nishapur in eastern Iran, and dates to the late $9^{\text {th }}$ or $10^{\text {th }}$ century. In Egypt stalactites were first found in the cornice of the lower part of the minaret at al-Guiyūšs̄ mosque (478 A. H. / 1085 A. D.) during the Fatimid period. The stalactites were used also to cover the corners of the transition zones of the domes between the circular shape of the dome and the square shape supporting it. The stalactites were used for the first time in the facades of the mosques, in the façade of al'Aqamr mosque (519 A. H. /1125 A. D.). The stalactites were continuously developed and used in all the Islamic periods in Egypt in facades and portals. Stalactites were used also as a decorative element in religious, funeral, public and residential establishments. In the $19^{\text {th }}$ and the beginning of the $20^{\text {th }}$ centuries the time of this study, the stalactites was used to decorate the entrances of Islamic buildings like the mosque of al- Imām alŠafa 'î(1303-1309A.H./1885-1891A.D.), the mosque of Sālih Abu Hadīd(1280-1284 A.H. /1863 -1867A.D.), the mosque of Qūsūn(1299-1311A.H./1873-1893A.D.) and the mosque 
circular forms, ending with a circle (Mìma). The soffit of the arch hood is decorated with two tiers of stalactites. The whole façade of the entrance block is adorned with continuous molding with circular forms. The façade of this part is crowned also with crenellations in the shape of trefoil plant leaf like the other parts. On both sides of the entrance block, there is a relieving arch mounting on two engaged columns with round shafts, each has a base and capital of stalactites.

\section{The MaUSOLEUM OF AL-HaĞ IBRĀHĪM ḤUSSIYN AL-ZAIYĀT}

This Mausoleum is located at Nağim al-Dīn Street in Bāb al-Nașr Cemetery (Fig.1). It was erected by al-Hağ ${ }^{33}$ Ibrāhīm Ḥussiyn al-Zaiyāt in (1340 A.H. / 1921 A.D.).

of al- Sayyidah Nafîsah(1314-1316A.H./1893-1895 A.D.), and the Mausoleum of alMi'allim Mușțafā Ibrāhīm al-Faḥām in this study. (pl.10,14). For More about the stalactites, See:

Andraw Petersen, (1996). Dictionary of Islamic Architecture, (Rout ledge, London and New York), 206-208; Al-Basha, Hassan, (1965). "The Muqarans, A genuine Characteristic of Islamic Art, its Early used and Development in Domes", Minber alIslam, no.5, 34- 37; Al-Basha, Hassan, (1965). "The Muqarnas; Its use in Islamic Doorways and Domes" , Minbar al- Islam , no.6, 22-25; Center for Planning and Architectural Studies, Principals of Architectural Design, p.442; Muhammed Amīn, Muḥammed, 'Alī Ibrāhīm, Laila, (1990). al-Muștaalhāt al-Mi 'māriyya fi al-Watāà iq alMamlukiyya, Dār a-Našr bi al-Ğam'a al-Amrikiyya, Cairo), 113;. Fahmī Karīm, Šāhinda, (1987). Ğawāma' Wa-Masğid, 366-374.

${ }^{32}$ The Continuous Molding (al- Ğift al-Lā' b): Molding is a strip of material with various profiles used to cover transitions between surfaces or for decoration. The molding is made from wood and stones. The molding as a geometrical decorative element is adorned nearly the most of entrances and windows of Islamic buildings of this era, like mosques, Sābīls, Mausoleums and also the civil buildings. In the $19^{\text {th }}$ and the beginning of the $20^{\text {th }}$ centuries the time of this study, the Continuous Molding was used to decorate the entrances of Islamic buildings like the Mausoleum al-Mi allim Muștafā Ibrāhīm al-Fahāam in this study (pl.10). For More about the Continuous Molding, See: 'Abdelrḥ̄m Ibrāhīm, Ğamāl, (1991). "al- Ḥuliyyat al-Mi māriyya a-Zuhrufiyya 'ala 'Amā'r al-Qāhira fi fi al- 'Așr al-Mamlukī al- Ğarkas̄̄",(Ph.d. Thesis,Faculty of Archaeology, Cairo University, 1991), 84-93; Muḥammed Rizq, 'Asām, (2000). Mu 'ǧam Muṣṭaalhāt al- 'Imārah, 66; Muḥammed Amīn, Muḥammed, 'Alī Ibrāhīm, Laila, (1990). al-Mușțaalhāt al-Mi'māriyya, 29.

${ }^{33}$ Al-Hağ: This title was given to the person who led the pilgrimage to the Ka'ba in Mecca. It was given also to the great persons (Pašwāt) in the Ottoman period in Egypt. This title is appeared in the foundation text of many Ottoman buildings in Cairo such as the foundation text of Manzil and Sabīl al-Kiridliyya (1041 A.H.) as it was mentioned the title of al-Hağ for (al-Hağ Muhammed ibn al-Marḥūm al-Hağ Sālim). For More, See: Mușțafa Barakāt, al-' Alqāb wa- al-Waẓā' if al- 'Uțmāniyya, 206-208. 


\section{THE DESCRIPTION}

This mausoleum has two facades. The western one is the main façade overlooking Nağim al-Dīn Street, while the eastern façade overlooking a side street. They are symmetrical and accurately identical in architectural and decorative design except for the height of the main façade that is one meter high (Fig.9, pl. 12).

THE WESTERN FAÇADE: It is the main façade of the mausoleum because it has the main entrance that is higher one meter than the rest of the facade wall. It is topped by a row of crenellations in the form of tri-foiled motifs. The entrance block begins with a single stone step leading directly to the entry opening. It is a rectangular opening with two-leaf wooden door with Iron castings. They have various floral decorative units. It is topped by an inscription in a square white marble slab. It records the name of the founder and date of construction preceded by a Qur'ānic verse.

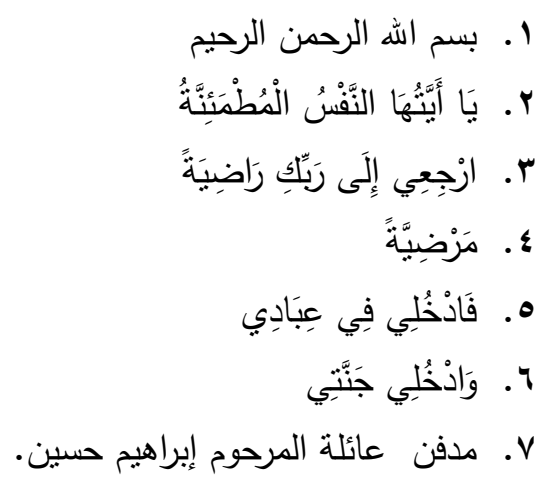

\section{The Transliteration}

1. Bismi Ilāhī ar-Raḥmāni ar-Raḥīm.

2. Yā 'Aiyatuhā An-Nafsu Al-Muțma'innah

3. Irji ' $\overline{\text { ' } I l a ̄ ~ R a b b i k i ~ R a ̄ o ̣ i y a t a n ~}$

4. Marḍiyah

5. Fādkhulī fi 'Ibādī

6. Wa Adhulī Ğannatī

7. Madfan 'Aā' ilt al-Marhūm Ibrāhīm Husssiyn ".

\section{The Translation}

1. "In the name of God, the Most Gracious, the Most Merciful

2. To the righteous it will be said, "O reassured soul ${ }^{34}$

3. Return to your Lord, well-pleased/

${ }^{34}$ Holy Qur'an, Surat al- Fağr, verse (27). 
4. And pleasing [to Him] $]^{35}$

5. And enter among my [righteous] servants ${ }^{36}$

6. And enter My Paradise" ${ }^{37}$.

7. The Mausoleum of the family of the late Ibrāhīm Hussiyn ".

It is adorned thoroughly by continuous molding with circular forms. In addition, it is topped by two rows of Stalactites. Each of these rows consists of seven Stalactites, in two levels of pendentives that are adjacent to the wall. On their upper part, before the end of the entrance, there is a foundational inscription. It is carried out on a rectangular white marble panel. It consists of two lines in high-relief Tulut script says that (pl. 13):

$$
\text { r ـ . أنثأ هذا المدفن الحاج إبراهيم حسين الزيات. }
$$

\section{The Transliteration}

1. 'Anša' Haḍā al-Madfan al-Hağ Ibrāhīm Ḥussiyn al-Zaiyāt.

2. Ibn al-Marhūm Hussiyn Ibrāhīm wa 'Á'ilatah Sanat 1340 A.H.Sanat 1921 A.D.).

\section{The Translation}

1. This Mausoleum was established by al-Hağ Ibrāhīm Ḥussiyn alZaiyāt.

2. The Son of the late Hussiyn Ibrāhīm and his family in 1340 A.H. in 1921 A.D.".

To the right and left of this panel, there are floral decorative units mediated by a circle including in its right side the word of his Majesty (اله), Allah, and in its left the word "محمد: Muhammad". This panel is also topped by a band of inscription containing a Qur'anic verse reads as follows:

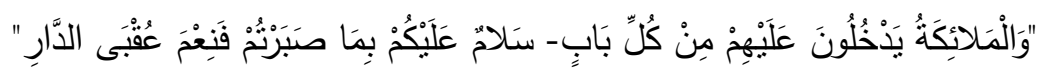

\section{The Transliteration}

Wa al-Malā'ikatu Yad ḩ ulūna 'Alayhim min Kulli Bābin Salāmun 'Alaykum Bimā Ș abartum Fani'ma 'Uqbā Ad-Dār.

\footnotetext{
${ }^{35}$ Holy Qur' an, Surat al- Fağr, verse (28).

${ }^{36}$ Holy Qur' an, Surat al- Fağr, verse (29).

${ }^{37}$ Holy Qur'an, Surat al- Fağr, verse (30).
} 


\section{The Translation}

And the angels will enter upon them from every gate, [saying] ${ }^{38}$, "Peace be upon you for what you patiently endured. And excellent is the final home ${ }^{39}$.

The entire panel is encircled by a stone fret. The entrance ends from the upper part with a row of trefoil plant crenellations. The architect executed three windows in this facade, one on the right side and the other two on the left side. They are symmetrical and accurately identical in architectural and decorative design. A two-leaf wooden door closes upon them from inside. It has some overlapping geometric shapes such as squares and polygons.

As for the exterior part, there are iron castings with various geometric decorative units topped by joggled vousiors ${ }^{40}$ ( Șanğat Mizrrah) and the Muqarnas which consists of five stalactites and two levels of pendentives adjacent to the wall. On both sides of the window, there is an embedded column with a circular shaft and a base. The architect decorated the entire facade in the corners with an embedded column consisting of a round shaft and a stalactite crown. In addition, there is a stone bench in front of the facade in its same length to be used for sitting while visiting the tomb.

\section{The SABĪL AL-HaĞ Ạ̣MEd AḤMED AL-SAMĀḤī}

This Sabīil ${ }^{41}$ is located at Nağim al-Dīn Street in Bāb al-Naṣr Cemetery (Fig. 1). It was established by al-Hağ Aḥmed Aḥmed al-Samāḥ̄ in (1332 A.H./ 1913 A.D.).

\footnotetext{
${ }^{38}$ Holy Qur'an, Surat al- Ra 'd, verse (23).

${ }^{39}$ Holy Qur'an, Surat al- Ra'd, verse (24).

${ }^{40}$ Joggled Voussoirs :The earliest example of joggled voussoirs is found in Roman architecture particularly in Spain and France where they are used in bridge construction, The joggled voussoirs were used for the first time in Islamic architecture in the lintel above the entrance of the greater enclosure at Qașr al- Hayr al-Šarqī (110 A. H., 728729 A.D). After that, the joggled voussoirs were developed and became characteristic feature of Ayyubid and Mamluk architecture, In Egypt, the earliest example of joggled voussoirs is found in the entrances of al- Hākim mosque in the Fatimid period. It appeared in this study in the mausoleum of Ibrāhīm Hussiyn al-Zaiyāt (pl.12, 13), for more See: Andraw Petersen, (1996). Dictionary of Islamic Architecture, 137; Ğamāl 'Abdelrḥ̄m Ibrāhīm, Ğamāl, al- Ḥuliyyat al-Mi' māriyya a-Zuhrufiyya, 22-37.

${ }^{41}$ Sabīl: The word Sabīl in Arabic means a path or a road. The Sabīl in Islamic architecture is a drinking fountain, charitably endowed to distribute free drinking water to the people, as a drink place. It is derived from the verb (Sabala) which means which means to let fall, drop, to let hang down and to pour water. In many situations, the Muslim to give water to his fellow men and animals, as a feature of charity that has a great reward in the hereafter day. The word Sabīl is mentioned in the Holy Qur' an 116
} 


\section{THE DESCRIPTION}

This Sabīl consists of a circular room for Tasbīl, which contains two windows for Tasbīl. The façade of the Sabīl takes the shape of a circular tower shaped structure ${ }^{42}$ (Fig.10, pl. 14). It overlooks the main Street of

times, For More, See: Mostafa, Salah Lamei, (1989). "The Cairene Sabīl, Form and Meaning" Muqarnas, no.6, (1989):33; Hāšim Ṭarbūš, Muhammed, (1995). "Asbilat alQarn al-Tāsi' 'Ašr fi al-Qāhira", (Master thesis, Faculty of Arts, South Valley University), 45- 47; Williams, Caroline, (1999). Islamic monuments in Cairo, the practical Guide, The AUC press, Cairo, 155.

${ }^{42}$ The Sabīl is appeared in Egypt in the beginning of the $6^{\text {th }}$ century of Higra. It is worth of mention that, the oldest known foundation text on a Sabīl is existed in Damascus. It is dated (470 A.H. /1077, A.D.), while the oldest surviving Sabīl in Cairo is the Sabīl of alNāsir Muḥammad Ibn Qalāwūn dated (726 A.H. /1326 A.D.), that is located next to the architectural collection of his father al-Sultan Qalāwūn in the street of al- Mu'izz lī Dīn Illah. In fact the architecture of the Sabīl as a place for drinking water is developed in the Mamluk and Ottoman periods in Egypt. The Sabīl in the Mamluk period is distinguished with the appearance of a special type of the large Tasbīl windows, which correspond with the purpose to which the Sabill was erected. The Sabīl windows consists of vertical iron grille intersected with another horizontal and connected to, through iron pommel to form squares from which the drinking tankards hanged from, the Sabīl windows were flanked by a row of marble joggled voussiors decorated with the red and white or black and white colures alternately. The Sabīl window also provided with a sitting marble or stone Mastaba in front of it, and was supported on stone stand and this Mastaba was specialized to put the drinking tankards. During the ottoman period the architecture of the Sabīl developed, and the Sabīl was commonly erected free standing, separated from the mass of the religious or civil buildings, such as the Sabīl of al-Amīr Muhammed (1014 A.H./1605A.D). The Ottoman Sabīls distinguished with a great care choosing their location, their architecture and ornaments as well of a great endowment to spend on these Sabīls to pay for the porters and to buy the Sabīl tools and requirements. The Sabīl in Ottoman period divide into two patterns for the design and formation of the building. In both patterns the Sabīl building includes a Sabīl and Kuttāb above in one block following the Circassian Mamluk deseign. In the $19^{\text {th }}$ and the beginning of the $20^{\text {th }}$ centuries the time of this study, the architecture of Sabill is developed and takes the shape of semi-circular façade like the Sabīl of Muḥammed 'Alī in al-Naḥssīn (1244 A.H. / 18281829 A.D.). The architecture of Sabīl is affected with the European styles of architecture like Rococo and Barouk. In this study the Sabīl of al-Hağ Aḥmed Aḥmed al-Samāḥ̄ takes the shape of semi- circular façade, and it contains two Tasbīl windows like the Sabīls of $19^{\text {th }}$ century in Cairo (pl.14). For More about the development of the architecture of Sabīl in Egypt, See: Mostafa, Salah Lamei, (1989). The Cairene Sabīl, 34-38; Hāšim Ṭarbūš, Muhammed, (1995). Asbilat al-Qarn al-Tāsi' 'Ašr, 47-48; Abd alWahab Amin, Nahed, (2002). "Monuments of Imam al-Shaf I Area and its Tourist Development", (Master Thesis, Faculty of Tourism and Hotels, Helwan University), 296-299; Ḥāmid al- Hussīn̄̄, Mạ̣mūd, (1988). Al-Asbila al'Uțmāniyya bi Madinat al-Qāhira (1517 A.H./ 1798 A.D.), (Maktabat Madbūlī, Cairo). 
Nağim al-Dīn with two Tasbīl windows ${ }^{43}$ (water dispensing Windows). Each window is covered with an iron metal grill. The Tasbīl windows are followed by three tiers of Stalactites that are adjacent to the wall. They are three decorative levels of Stalactites, followed by an inscription between the two blocks of Tasbill windows. The inscription is carried out on a rectangular white slab of marble. It consists of a Qur'anic verse in basrelief Riq'a script in five lines says that (Fig.5, pl. 15):

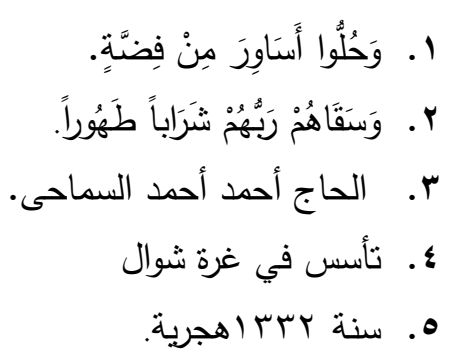

\section{The Transliteration}

1. Wa Hullū 'Asāwira Min Fiḍdatin.

2. Wa Saqāhum Rabbuhum Šarābāan Țahūrā.

3. al-Hağ Aḥmed Aḥmed al-Samāhī.

4. Ta'asasa fi Gurrat Šawwāl.

5. Sanat 1332 Hijriya"

\section{The Translation}

1. And they will be adorned with bracelets of silver.

2. And their Lord will give them a purifying drink. ${ }^{44}$

3. Al-Hă̆ Aḥmed Aḥmed al-Samāhī.

4. Established in the beginning of Šawwāl.

5. In the year of (1332 A.H.).

The Tasbīl windows are crowned with a pointed $\operatorname{arch}^{45}$ in the same Iron shutter that can be closed upon it from outside. It is decorated with

\footnotetext{
${ }^{43}$ Tasbīl windows: The Tasbīl windows are considered one of the main elements in the formation of Sabīl. It crowned with the semi- circular or pointed arch or any type of arches. It closed by brass or iron or bronze windows of grille. The number of windows differs from Sabīl to other according to the area of Sabīl. The Tasbīl windows of $19^{\text {th }}$ century Sabīls in Cairo are decorated with Rococo and Barouk ornaments. In this Study Tasbīl window of the Sabīl of al-Hağ Aḥmed Aḥmed al-Samāḥī is crowned with pointed arch and covered with iron grille that decorated with geamterical decorations (pl.14).

${ }^{44}$ Holy Qur'an, Surat al-'Insān, verse (21).

${ }^{45}$ The pointed arch: The earliest example of pointed arches in Egypt was found in 'Amr ibn al- 'As mosque, and later was used in different Islamic buildings. The pointed arch was developed and takes some shapes like the pointed arch with three centers, and
} 
various geometrical patterns. Below the shutter, there are three circular openings from which people can drink water. Each Tasbīl window is topped by two octagonal Stalactites, one from the side and the other from the pendentive. Each Tasbīl window is adjacent to two engaged columns in the same wall. They take the form of an octagonal shaft from ends with Stalactite base and capital. The lower part of the Sabīl block is crowned with a row of simple-shaped Stalactites. The façade of the Sabil is topped by a row of crenellations on the shape of trefoil plant leaf.

\section{The Touristic Study}

The Cemetery Bāb al-Nașr needs a great effort to be developed and put on the Egyptian tourism map. This cemetery contains a great number of neglected Funeral establishments. It includes a lot of tombs of 'Ulamā' (Muslim scholars), 'Awliya' (guardians), jurists of Islam and historians. This area is a meant for many people to visit the tombs of 'Awliya' in their birth celebration (al-Mawlid).In this study, the researcher will offer some solutions and suggestions to develop this area.

\section{The Obstacles of Touristic Development at BāB al-Nașr Cemetery}

The most important obstacles that facing the tourist development of the monuments of Bāb al-Nașr Cemetery are summarized in:

- The problem of the urban deterioration of the area of Bāb al-Nașr cemetery. This includes the absence of construction controls represented by the urban encroachment on the archeological site, which leads to the loss of its tourist attractions. ${ }^{46}$

- Bad conditions of roads inside the cemetery of Bāb al-Nașr. The main road of the cemetery (Nağim al-Dīn Street) lacks most of the vital utilities.

- The lack of water closets, ambulances or security patrols - whether stable and mobile - which provide reassurance in the hearts of the local citizens and visitors.

- Lack of lighting or green parks to provide the visitors with a sense of psychological comfort.

pointed arch with four shapes. This type of arches is appeared in the Tasbīl windows of the Sabīl of al-Hağ Aḥmed Aḥmed al-Samāḥ̄ in this study (pl.14). For More, See: Șālah Lam 'aī Muștafa, (1977). A- Turāt al-Mi 'mārī, p.97.

${ }^{46}$ Kamāl Madbūlī, Muṣtfa, (1992). "'I'ādāt Ta'hīl al-Manāṭq al-Markaziyya ḍāt al-Qīma al-Siyāhiyya al- Tārih̆ iyya fi al-Diwal al-Nāmiyya,Dirast Ḥāla al-Qāhira", (Master Thesis, Faculty of Engineering, Cairo Univeristy), 199. 
- The absence of responsible individuals or officials working under the auspices of archaeological authorities, or Tourism Police or the Ministry of Tourism or Cairo Governorate or any other entity to be responsible for Bab al-Nasr Cemetery, its monuments, preservation and development.

- The area is free of any entertainment or services such as restaurants and multi-storey hotels.

- The problem of traffic congestion, which leads to a long waiting period and loss of tourist's time. This problem exacerbates during the celebration of 'Ahl al-Bayt Mawālids (Birth Anniversaries) especially al-Lila al-Kibira (The Grand Night), such as the famous Mawlid of Sayd̄̄ Yūnis al-S'adī which held annually in 14-22 Ğumādī al-'Ula.

- The problem of illiteracy and lack of religious tourism awareness of the value of religious shrines and their importance. This is due to the fact that illiterate visitors represent a large percentage of the number of visitors during the establishment of Mawālid celebrations. In addition, some of these visitors may have irresponsible behaviors during the visit, and their goals may not agree with the etiquette of visiting the righteous. These behaviors may lead to chaos that affects the atmosphere of worship, as happens in the mausoleum of Sheikh Younis al-Sa'di at Bab alNasr cemetery.

- The problem of the narrow yards and fields of some shrines, which limits assimilating large numbers of visitors or participants in these religious celebrations.

- The problem of the inhabited courtyards. A lot of mausoleums in Bāb al-Nașr cemetery are inhabited with people.

\section{The Current Situation of Bāb al-Nașr Cemetery}

After reviewing the current situation of the area and the problems it faces, the situation can be assessed as follows:

- The continuous deterioration of the current environmental and urban conditions of the area led to the loss of a large part of its aesthetic, historical and archaeological value.

- The status reflects a serious waste of a valuable cultural and religious resource, especially in light of the archaeological and historical importance of this area and its relationship to Islamic history.

- This cemetery needs a comprehensive administrative system to regain its value as a distinctive religious site. It is in dire need of a 
comprehensive tourism development plan. In addition, it has no economic return due to its nature as a cemetery with useless ruins. Despite the presence of many tourist and archaeological attractions in this site, it became a haven for the commons, criminals and street children.

- In order to become a tourist attraction, it is important to provide this area with all modern facilities and services for convenience of tourists of all classes. Monuments are unexploited resources that should be developed to fit tourism in the context of understanding the close relationship between the monuments and tourism. The coherent relationship requires combining both into a comprehensive plan with mutual non-conflicting objectives.

\section{ReCOMMENDATIONS FOR Developing THE Monuments of BĀB AL-NaȘR CEMETERY}

Bāb al-Nașr cemetery is a significant archaeological and historical site due to its distinct location in an important area of Islamic Egypt as a natural extension of al-Mu'izz and Fatimid Cairo streets. In addition, it has a pivotal location between old Cairo and modern Cairo which facilitated connecting it to the Ring Road, Munsh'at Nasser and Autostrad Road. Moreover, it once located on the road of pilgrimage and armies. Hence, the researcher develops several suggestions and basic projects for developing religious tourism and highlighting the position of Bāb al-Nașr Cemetery and the surrounding area on the tourist map of Egypt.

- Reviving the northern gates of Islamic Cairo (Bāb al-Futūh and Bāb al-Nașr) by removing the existing buildings and transgressions in al- 'Uțūf district, restoring the demolished part of the northern wall and restoring the situation as it was upon establishing Cairo.

- Developing a project for sound and light that tells the history of this ancient city.

- Turning a part of Bāb al-Nașr Cemetery into a park and a tourist complex, planning a distinctive design such as the memorial in the form of an Islamic tower containing pictures and biographies of the great historians, scholars and the sheikhs buried in the cemetery of Bāb al-Nașr whose tombs faded into the oblivion.

- The need to implement a sound and light project in the yard facing the right side of Bāb al-Nașr to narrate the story of Islamic conquest of Egypt and establishing the Islamic capitals of Egypt. It should shed light upon the monuments of this important area. 


\section{CONCLUding REMARKS}

In the light of this descriptive and touristic study, the researcher concluded the following:

- The study dealt with six Islamic monuments represented by five funeral mausoleums and one Sabīl established at the nineteenth and the beginning of the twentieth centuries, published for first time.

- The study highlighted the diversity of decorations on the facades of these courtyards, whether geometric, floral or inscriptional decorative units.

- Hence, the importance of this research is clear as it directs the attention of researchers and specialists of Islamic monuments to this new collection of Islamic monuments.

- The researcher recommends increasing the awareness to their significance and taking the necessary procedures for their registration upon the list of Islamic monuments.

- The study pointed out to some Islamic titles as stated in the foundational or renewal inscriptions of the monuments under investigation.

- The study stressed the importance of tourism development for Bāb al-Nașr Cemetery in Cairo and enlisting it's upon the map of religious tourism in Cairo. It also stressed the need to develop a media plan to highlight the advantages of this area and direction the attention of tourism companies to its importance.

- The study referred to some Islamic architectural elements that appeared on façades of courtyards and Sabīls.

- The study pointed to some personalities, which were identified from the foundational texts on the monuments under investigation.

- The study confirmed the use of architectural and decorative elements in the nineteenth and twentieth centuries. 


\section{REFERENCES}

\section{The Arabic Sources}

The Holy Qur'an.

Al- Ğabrty ('Abdalrahmān ibn Hassan d.1249/1825), (1998) 'Agā'b alAtāar fi el-Trāğm wa-l- Ahbār, 4 Volumes, ed. 'Abdelrhịim 'Abdelrḥman 'Abdelrḥ̄im, Dār al-Kutub al-Mișriyya, Cairo.

Al- Sahawī (al-Hāfiz Šams al-Dīn Muhammed Abu al- Hīr Muhammed ibn 'Abdalrman, d. 902/1446), (1968) Tuhfat al-'Hbāb wa Bugigiyat aṬulāb fi al- Hiițat wa al-Mazārāt wa al-Biqā' al-Mubārakāt, Maktabat al-Kuliyāt al-Azhariyya, Cairo.

Al-Maqrīzī (Taqiy al-Dīn Aḥmad ibn 'Alī al-Maqrīzī, d. 845/1442), (2001) 'It āz al- Hunfā fí 'Ahbār al-'A' imah al- Fāțimiyīn al-Hulfā, 3 Volumes, ed. Muhammed 'Abdelqadir Aḥmad Riḍa, Dār al-Kutub al'Ilmiyya, Beirut.

Al-Maqrīzī, (Taqiy al-Dīn Aḥmad ibn 'Alī al-Maqrīzī, d. 845/1442), (1998) al-Mawā' iz wa-l-i 'tibār fỉ dikr al-Hitatạ wa-l-ātār, 3 Volumes, ed. Muhammed Zinhum,Madiḥa Elšrqawī, Maktabat Madbūlī, Cairo.

Al-Qalqašandī (Abu al-'Abbās Aḥmad ibn 'Alī, d. 821/1418), (1914) Șubḥ al-a'šā fị șinā'at al-inšāa, 14 Volumes, Dār al-Kutub alMișriyya, Cairo.

Ibn 'Abd-el-Zāhir (Muhiȳī al-Dīn Abu al-Faḍl 'Abdallah ibn 'Abd-elZāhir al-Mașrī, d. 692/1293), (1996) al-Rawḍa al-Bahiyya al-Zāhira fi Hițat al-Mu'ziyya al-qāhira, ed. A.F. Sayyid, Maktabat al-Dār al'Arabiyya lilkitāb, Cairo.

Ibn Hुilkān (Abu al- 'Abbās Aḥmad ibn Muhammed al-Šāfi 'ī, d 681/1275), (1987) Wafiyāt al- 'Aiyān wa 'Anba' 'Abnā' al-Zamān, 8 Volumes, ed. 'Iḥsān 'Abbās, Dār Șādir, Beirut.

Ibn Tag̉rī Bardī (Ğamāl al-Dīn Abī al-Mahāsin Yūsif, d. 874/1470), (1963) al-Nuğūm al-Zāhirah fi Milūk Miṣr wa- al-qāhira,ed. Muhammed Ramzī, 16 Volumes, Nushah Muṣawarah min Dār alKutub al-Mașriyya, al-M'ūssa al-Mașriyya li- al-Ta' līf wa al-Našr, Cairo.

\section{The ARABic REFERENCES}

'Abdelfatāh 'Abdelwahāb, 'Abdelwahāb, (2006) al-Ṭirāz al-Fan̄̄ wa- alMi 'mārī li Masāğid al-Qğhirah fi al-Qarn al-tālit 'Ašr al-Hiğrī (12151318 A.H.) al-Tāsi' 'Ašr al-Milādī (1800-1899 A.D.), Master. Thesis, Faculty of Archaeology, Cairo University.

'Abdelrḥ̄m Ibrāhīm, Ğamāl, (1991) al- Huliyyat al-Mi'māriyya aZuhrufiyya 'ala 'Amā'r al-Qāhira fi fi al- 'Așr al-Mamlukī alĞarkasī, Ph.d. Thesis,Faculty of Archaeology, Cairo University. 
Al-Bāša, Ḥassan, (1978) al-' Alqāb al-'Islāmiyya fi al- Tārīḥ wa -alWatāà q wa-al-'Ațār, Dār al-Nahḍa al- 'Arabiyya, Cairo.

Al-Bāša, Ḥassan, (1965) al-Funūn al-'Islāmiyya wa al-Waẓ à'f 'alā al'Atāar al- 'Arbiyya, Dār al-Nahḍa al-'Arabiyya, Cairo.

'Alī Nașra,Muḥammed, (2001) Ğamāliyyat al-Kitbāt al-'Arbiyya fi al'Imārah al-Islāmiyya Kamadḩal li-Tağmīl Wağhāt al-Mabānī, Ph.d. thesis, Faculty of Art Education, Hilwān University.

Al-Sa '̄id Suliymān, Aḥmad, (1979) Ta'ṣil ma Warad fi Tarīh al- Ğabrty min a-Dah̄īl, Dār al-Ma rif, Cairo.

Barakāt, Muștafa, (2000) al-' Alqāb wa- al-Waẓā' if al- 'Uțmāniyya,Dirāsa fi Tațwur al-' Alqāb wa- al-Waẓā' if mund al-Fatḥ al- 'Uțānī li Miṣr ḥatā 'Iilg̀à' al- Ḩilāfa al- 'Utmāniyya, Dār Garāib li al- Ṭibā'ah wa -al -Nšar wa al-tawzī' ${ }^{\prime}$ Cairo.

Fahmī Karīm, Šāhinda, (1987) Ğawāma ' Wa-Masğid 'Umarā' al- Nāṣir Muhammed ibn Qalāwūn, Ph.d. Thesis,Faculty of Archaeology, Cairo University.

Fatḥ̄ al- 'Azhrī, Tarwat, (2016) Ğabānt Bāb al-Nașr in Cairo wa R'uiyya šāmilah li Waḍ 'ihā 'Alā Huarițat al-Siyyaḥah al-Dīniyyah wa al-' Iršāod al-Siyyāhīi, Ph.d. thesis, Faculty of Tourism and Hotels, Minia University.

Ǧum 'a, Ibrāhīm, (1979) Qiṣat al-Kitāba al- Arbiyya, Dār al-Ma'ārif, Cairo.

Ḥamdī al-Manāwī, Muḥammed, al-Wizārah wa-al-Wuzāra' fi al- 'Aṣr alFāțimī, Dār al-Mā' rif bi Mișr, Cairo.

Ḥāmid al- Ḥussīn̄i, Mạ̣mūd, (1988) al-Asbila al- 'Uțmāniyya bi Madinat al-Qāhira (1517 A.H./ 1798 A.D.), Maktabat Madbūlī, Cairo.

Hāšim Țarbūš, Muhammed, (1995) Asbilat al-Qarn al-Tāsi' 'Ašr fi alQāhira, Master. Thesis, Faculty of Arts, South Valley University.

Kamāl Madbūlī, Muștfa, (1992) 'I'ādāt Ta'hīl al-Manāțq al-Markaziyya dāt al-Qīma al-Siyāhiyya al- Tārih iyya fi al-Diwal alNāmiyya,Dirast Hāala al-Qāhira, Master Thesis, Faculty of Engineering, Cairo Univeristy.

Muhammed Amīn, Muhammed, 'Alī Ibrāhīm, Laila, (1990) al-Mușțaalhāt al-Mi 'māriyya fi al-Watāà iq al-Mamlukiyya, Dār a-Našr bi al-Ğam 'a al-Amrikiyya, Cairo.

Muhammed Ibrāhīm, Wafă', (2003) al-Ruh ām fi al- 'Aṣr al-Mamlukī alĞarkas̄i bimadīnat al-Qāhira, Dirāsa 'Atiriyya Faniyya, Master Thesis, Faculty of Arts, Tanta University.

Muḥammed Rizq, 'Asām, (2000) Mu' ğam Mușțaalhāt al-'Imārah wa- al Funūn al-Islāmiyya, Maktabat Madbūlī, Cairo.

Nazīf, 'Abdelsalām, (1989) Dirasāt fi al- 'Imārah al-'Islāmiyya, al-Hay'a al-Mișriyya al-' Âmma li-l-Kitāb, Cairo. 
Șālah Lam aī Muṣtafa, (1977) al- Turāt al-Mi mārī al-Islāmī fi Miṣr, Dār a-Nahḍah al- 'Arabiyya, Beirut.

Taiymūr, Aḥmad, (1950) al-Rutab wa- al-'Alqāb al-Miṣriyya, Dār alKitāb al-'Arabī, Cairo.

\section{THE FOREIGN REFERENCES}

Abd al-Wahab Amin, Nahed, (2002) Monuments of Imam al-Shaf I Area and its Tourist Development, Master Thesis, Faculty of Tourism and Hotels, Helwan University.

Al-Basha, Hassan, (1965) "The Muqarnas; Its use in Islamic Doorways and Domes", Minbar al- Islam, no. 6.

Andraw Petersen, (1996) Dictionary of Islamic Architecture, Rout ledge, London and New York.

Center for Planning and Architectural Studies, Center for Revival of Islamic Architectural Heritage, Principals of Architectural Design and Urban Planning During the Different Islamic Ears, Organization of the Islamic Capitals and Cities, Jedda, Saudi Arabia, 1992.

Creswell (K.A.C): (1940) Early Muslim Architecture, Oxford, London, II. Hamad Safady, Yassin, (1987) Islamic Calligraphy, Thames and Hudson, London.

Hassan Hemeda, Hosam, (2007) Islamic Archaeological Sites in alĞamāliyya street in Cairo and their Tourist Development, Ph.d. thesis, Faculty of Tourism and Hotels, Minia University.

Howary et Rached, (1932) Steles Funeraires, Le Caire, Tome I.

Mostafa, Salah Lamei, (1989) "The Cairene Sabīl, Form and Meaning" Muqarnas, no.6.

Williams, Caroline, (1999) Islamic monuments in Cairo, the practical Guide, The AUC press, Cairo. 


\section{Figures}

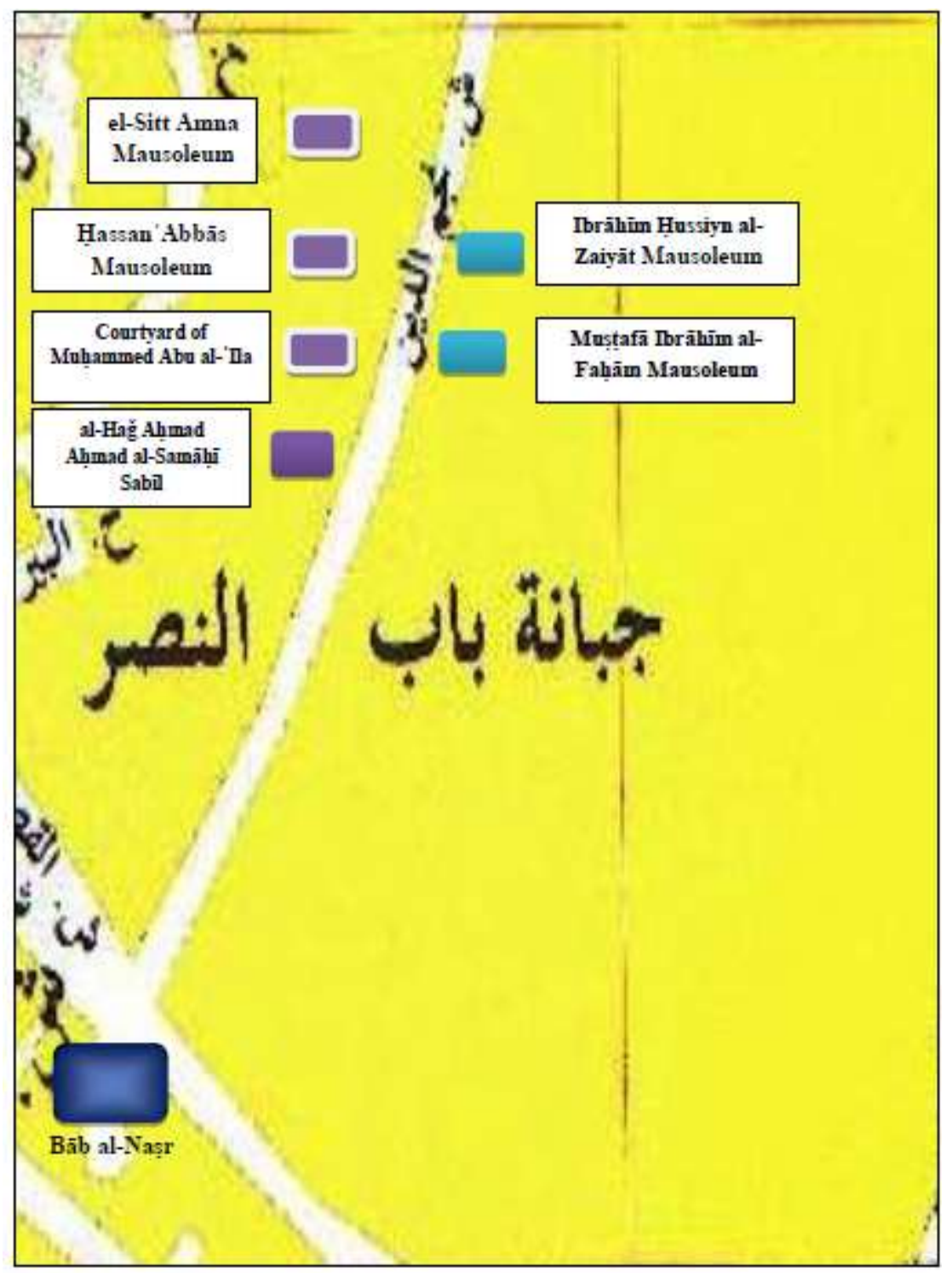

Fig. 1 Cairo Map represented Some Monuments of Bāb al-Naṣr Cemetery (Made by researcher) 


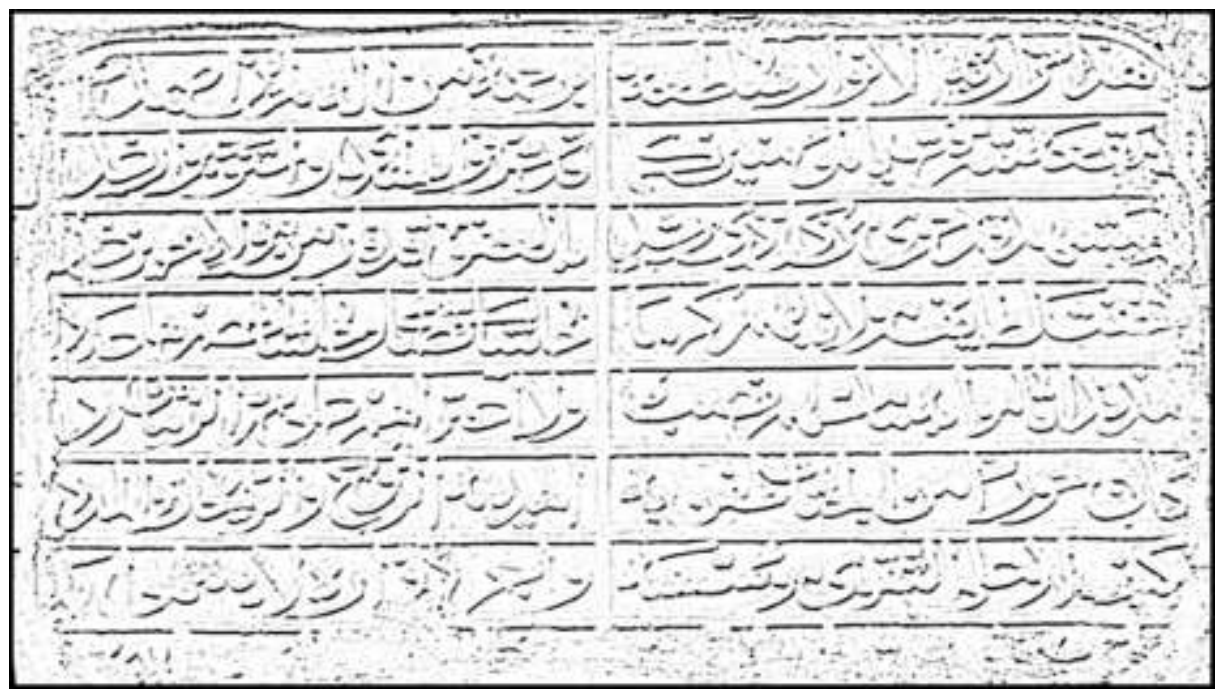

Fig. 2 Tulut Seventh Poetic lines upon the Entrance of the Mausoleum of elSitt Amna

(Made by Researcher)

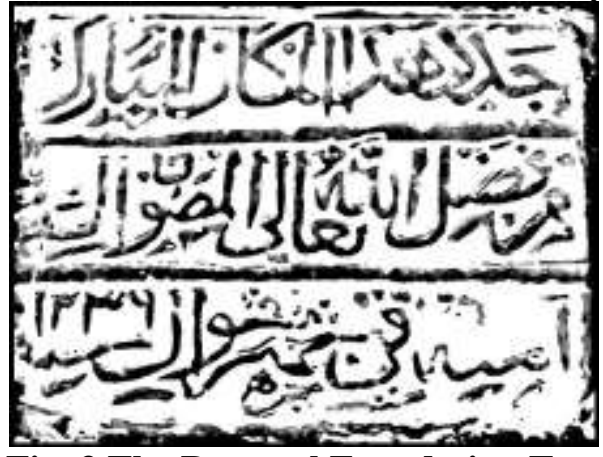

Fig. 3 The Renewal Foundation Text of the Mausoleum of el-Sitt Amna (Made by Researcher)

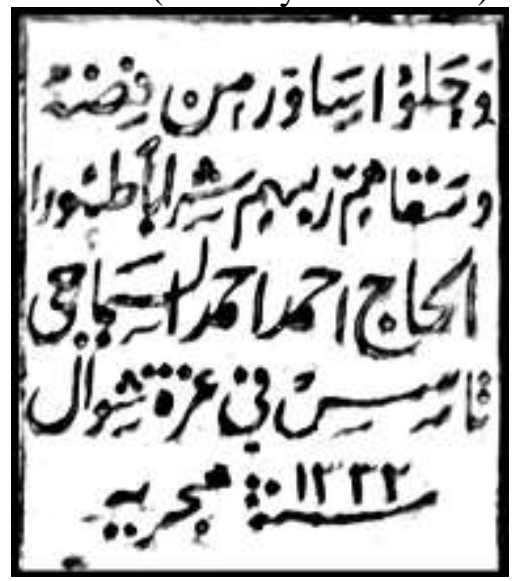

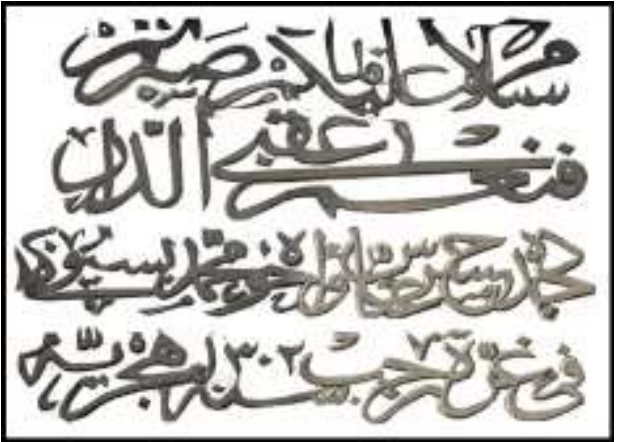

Fig. 4 The Renewal Foundation Text Mausoleum of Hassan'Abbās (Made by Researcher)
Fig. 5 The Foundation Text of the Sabīl alHağ Aḥmad Ạ̣mad al-Samāḥī (Made by Researcher) 


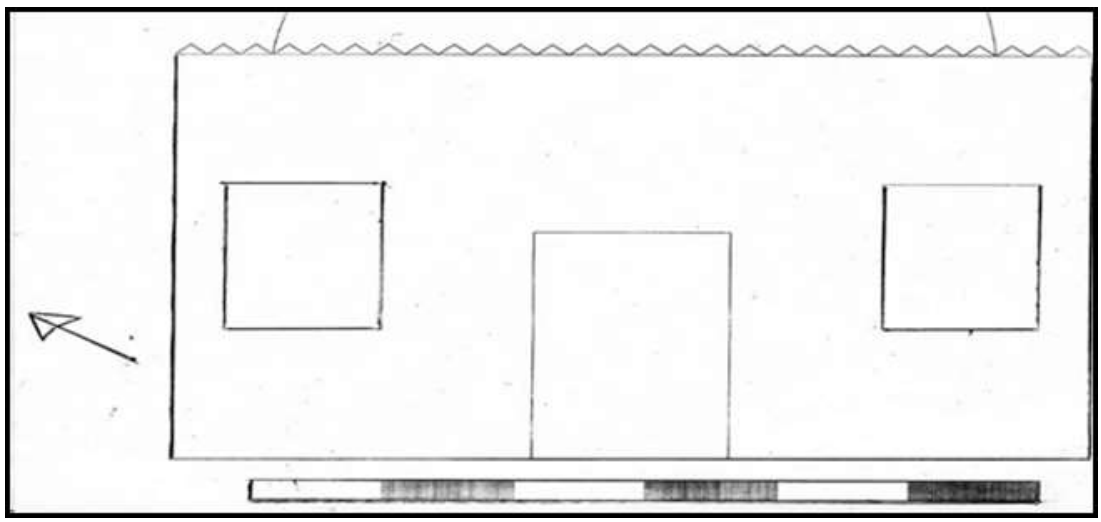

Fig. 6 The Eastern Facade Courtyard of Muḥammed Abu al-' Ila Made by Researcher)

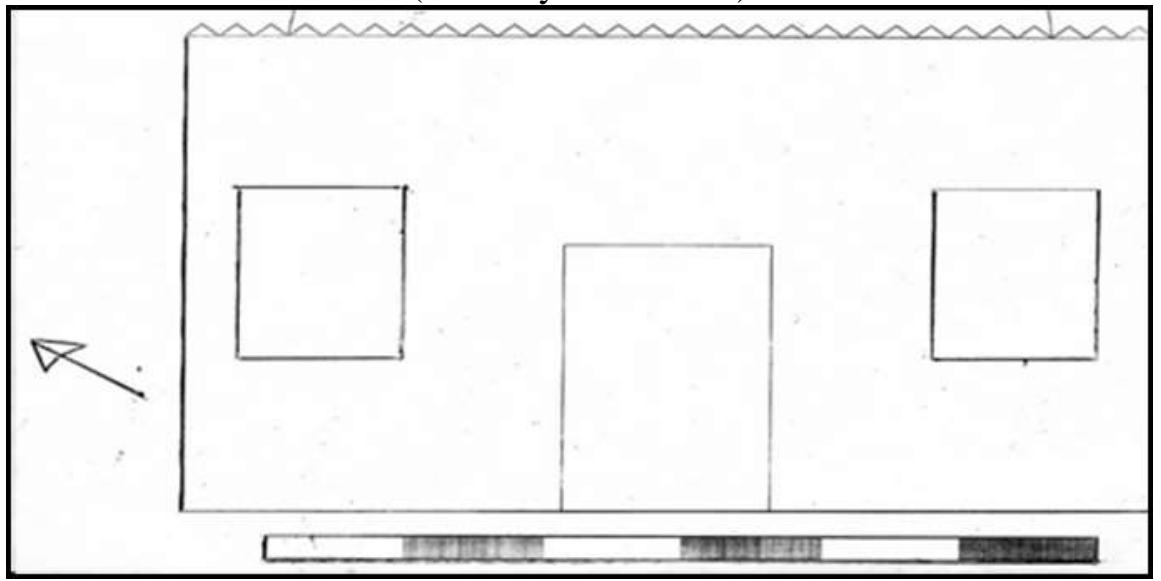

Fig. 7 The Northern Facade of Ḥassan 'Abbās Mausoleum

(Made by Researcher)

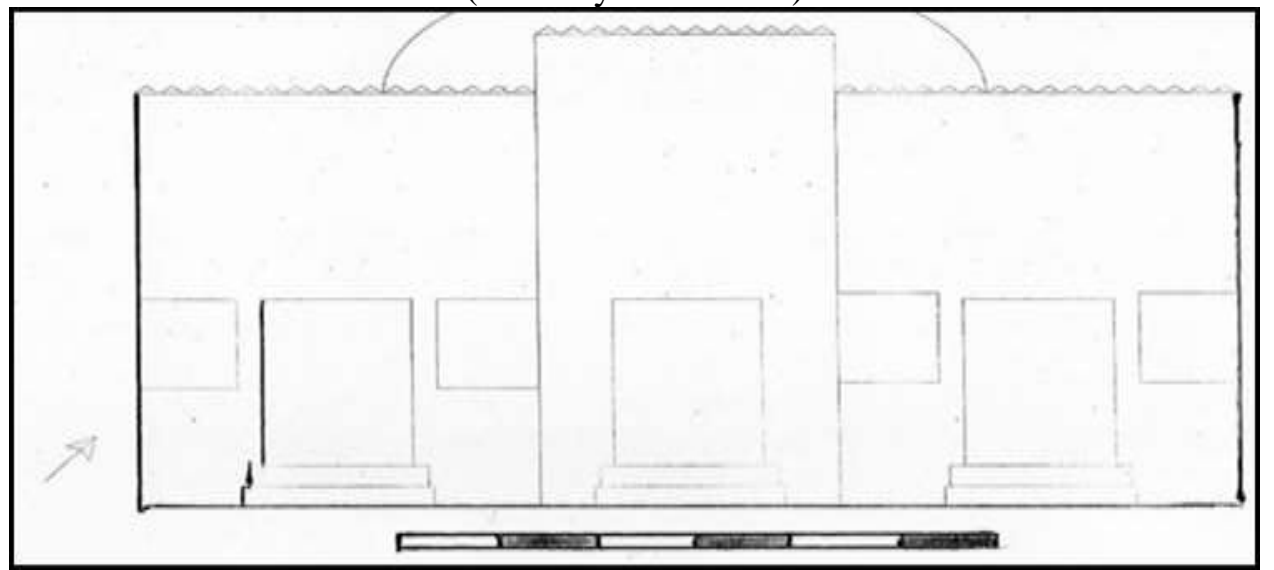

Fig. 8 The Northern Facade of the Mausoleum of Muṣtafā Ibrāhīm al-Faḥām (Made by Researcher) 


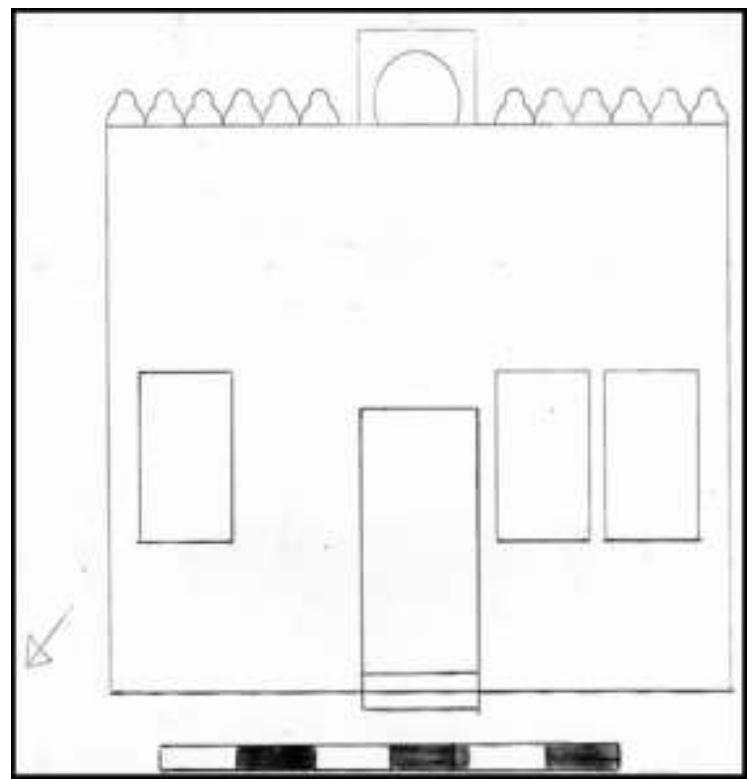

Fig. 9 The Northern Facade of the Mausoleum of Ibrāhīm Ḥussiyn al-Zaiyāt (Made by Researcher)

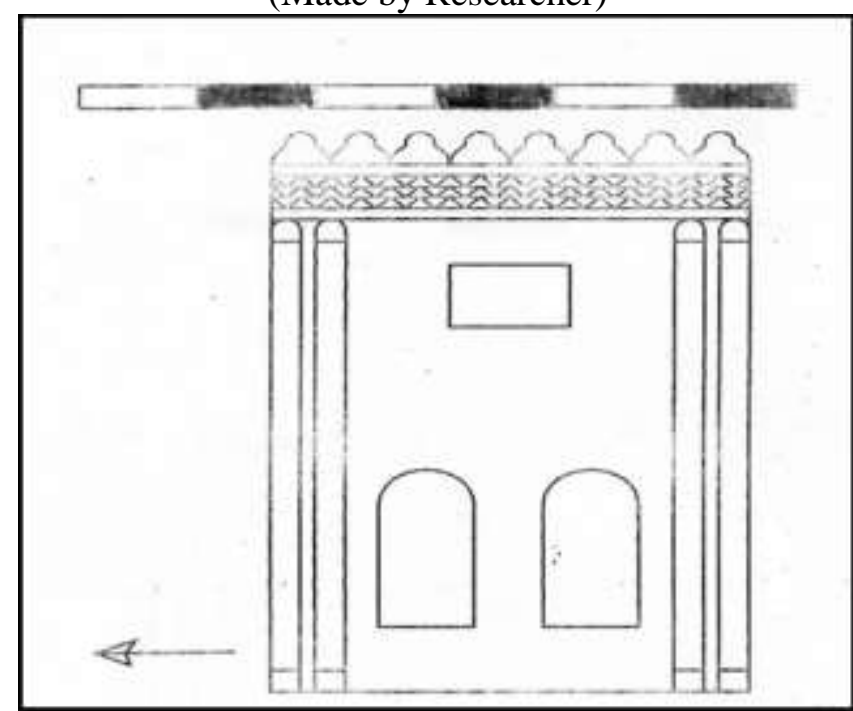

Fig. 10 The Eastern Facade of the Sabīl al-Hağ Aḥmad Aḥmad al-Samāḥī (Made by Researcher) 


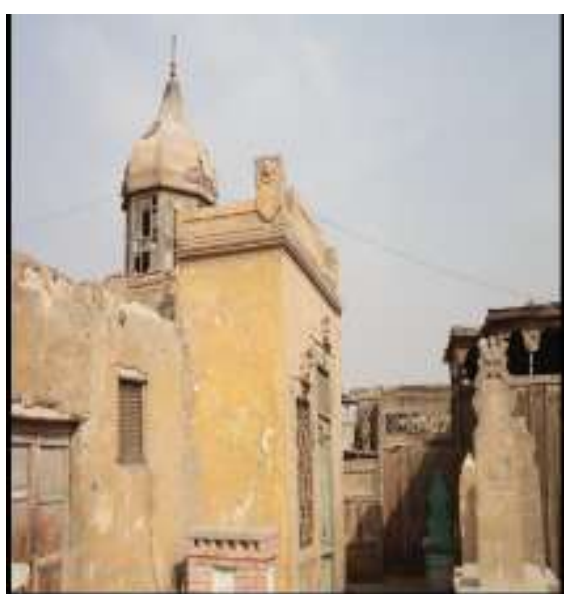

Pl. 1 The Façade of the Courtyard of Muhammed Abu al-' Ila (The Researcher)

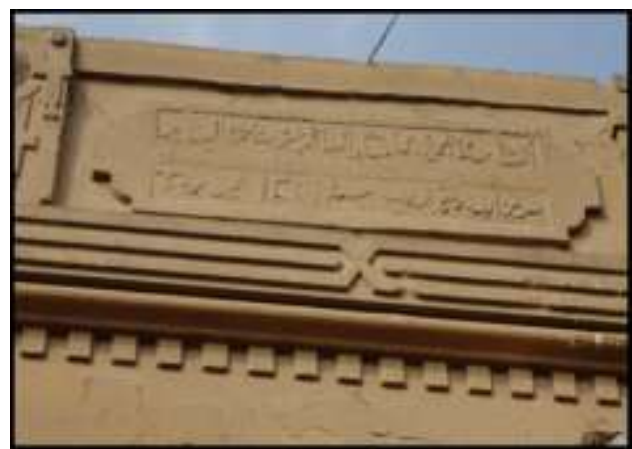

Pl. 3 The Foundation Text of the Courtyard of Muḥammed Abu al-'Ila (The Researcher)

Pl. 5 The Main Façade of the Mausoleum of el-Sitt Amna (The Researcher)

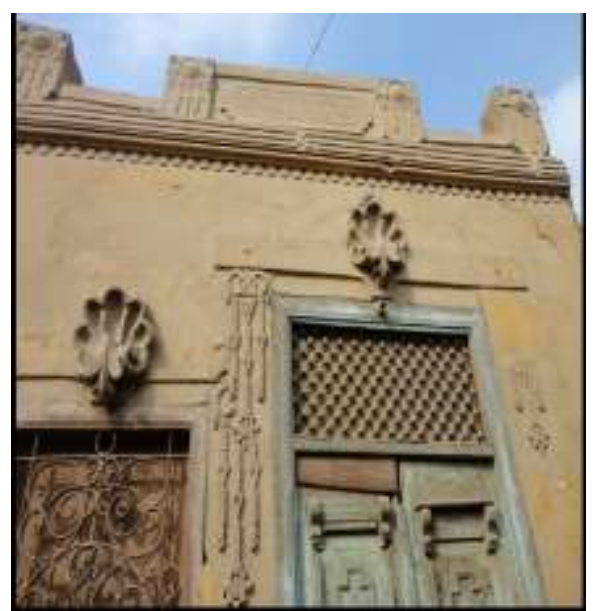

Pl. 2 The Main Entrance of the Courtyard of Muhammed Abu al'Ila

(The Researcher)

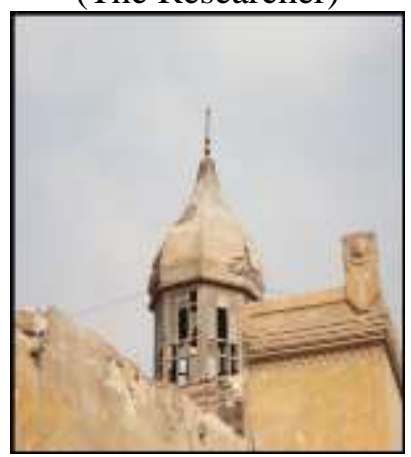

Pl. 4 The Shape of the Dome of the Courtyard of Muhammed Abu al'Ila

(The Researcher)

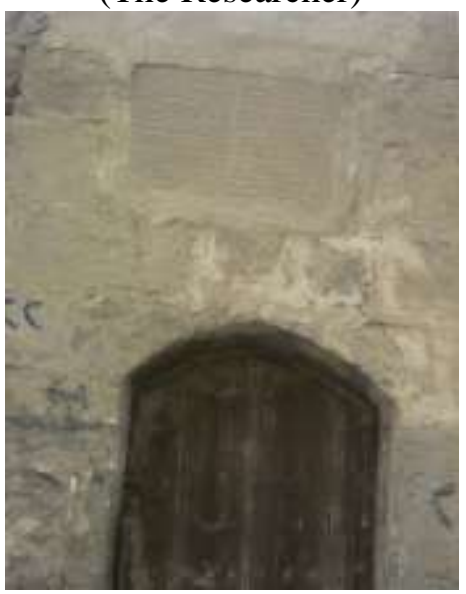




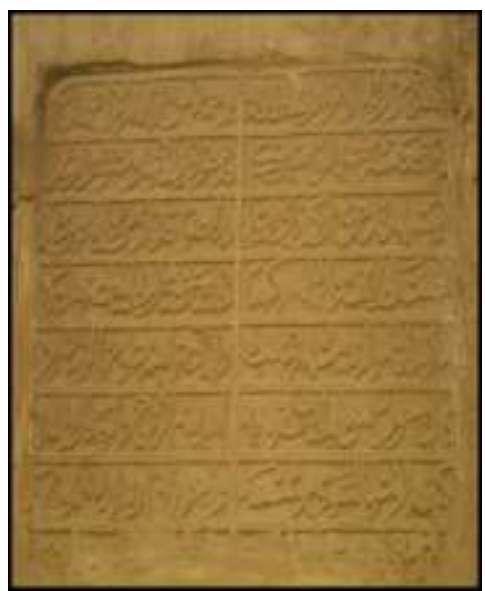

Pl. 6 The Tulut Seventh Poetic lines Text of the Mausoleum of el-Sitt Amna (The Researcher)

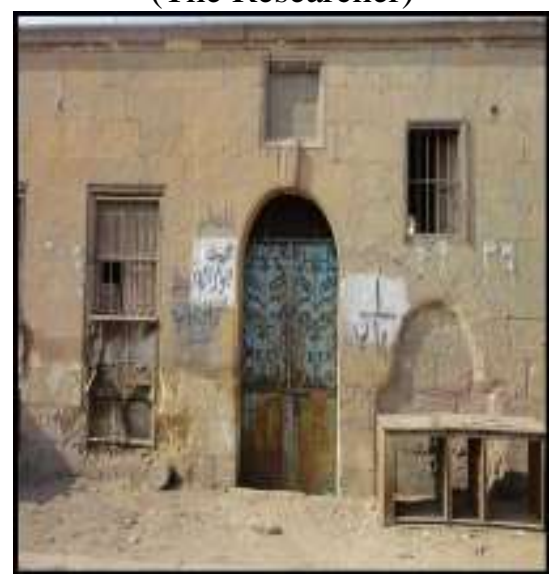

Pl. 8 The Main Façade of the Mausoleum Hassan 'Abbās (The Researcher)

Pl. 10 The Main Façade of the Mausoleum Muṣtafā Ibrāhīm al-Faḥām (The Researcher)

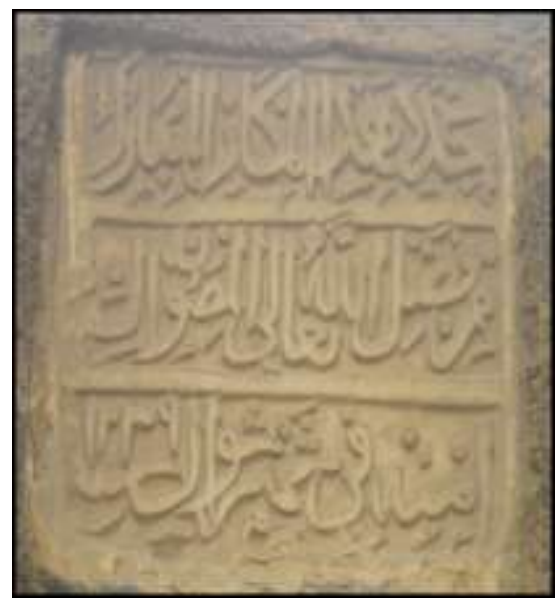

PI .7 The Foundation Text of the Mausoleum of el-Sitt Amna

(The Researcher)

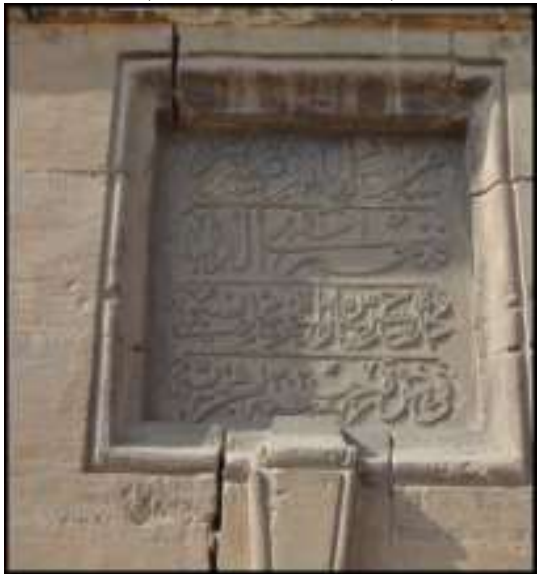

Pl. 9 The Foundation Text of the Mausoleum Hassan 'Abbās (The Researcher)

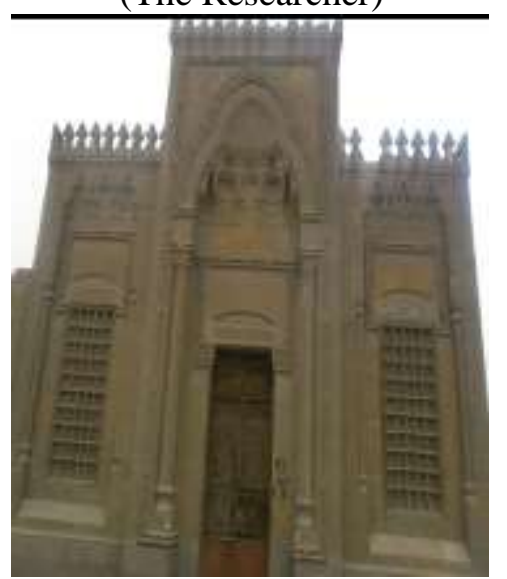




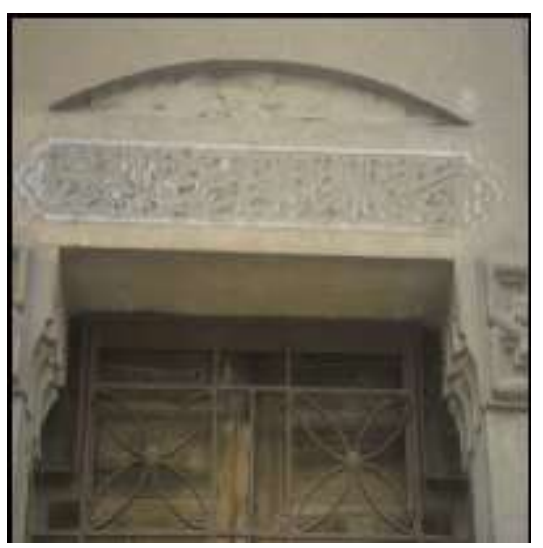

Pl. 11 The Foundation Text of the Mausoleum of Muștafā Ibrāhīm alFaḥām

(The Researcher)

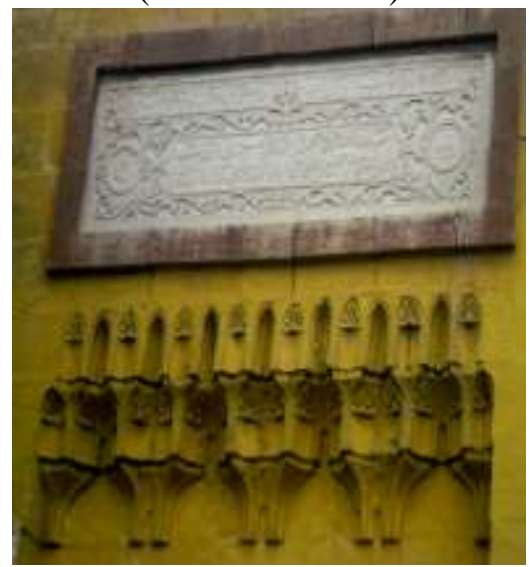

Pl. 13 The Foundation Text of the Mausoleum of Ibrāhīm Ḥussiyn alZaiyāt

(The Researcher)

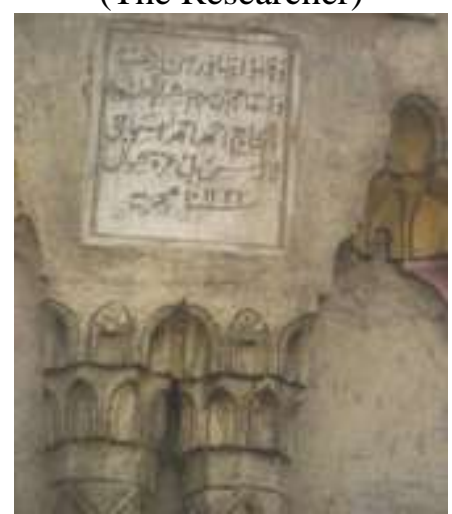

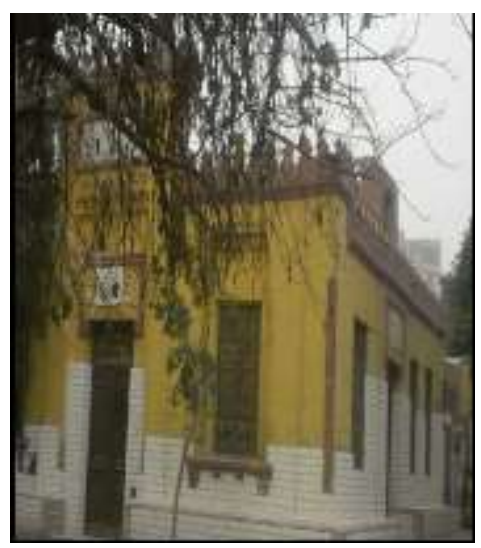

Pl. 12 The Façade of the Mausoleum of Ibrāhīm Ḥussiyn alZaiyāt

(The Researcher)

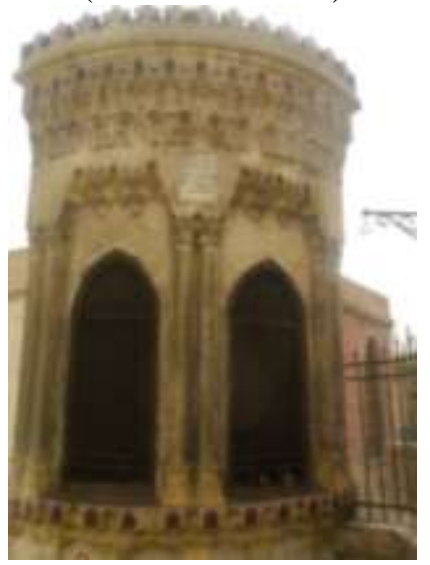

Pl. 14 The Eastern Facade of the Sabīl al-Hağ Aḥmad Aḥmad alSamāḥī

(The Researcher)

Pl. 15 The Foundation Text of the Sabīl al-Hağ Aḥmad Aḥmad alSamāḥi

(The Researcher) 